
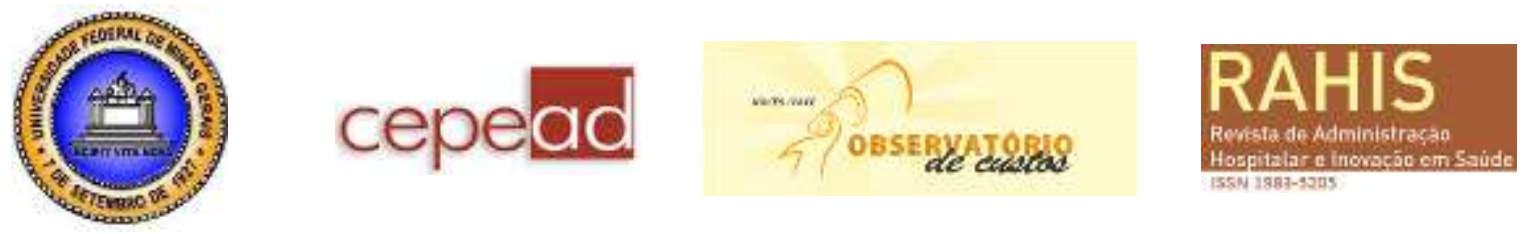

\title{
A GARANTIA DE ACESSO À SAÚdE E AS REGRAS DE REPARTIÇÃO DA COMPETÊNCIA ENTRE OS GESTORES
}

\section{ENSURING ACCESS TO HEALTH AND THE REGREAS OF ALLOCATION OF COMPETENCE AMONG MANAGERS.}

\section{GARANTIZAR EL ACCESO A LA SALUD Y LOS REGREAS DE REPARTO DE COMPETENCIAS ENTRE LOS GERENTES.}

\author{
RENATO LUÍS DRESCH \\ Tribunal de Justiça do Estado de Minas Gerais \\ vfazendamunicipal4@tjmg.jus.br
}

\begin{abstract}
Resumo
A saúde é um direito humano fundamental reconhecido na Constituição da República Federativa do Brasil. Trata-se de um direito de todos e dever do Estado, cumprindo à União, aos Estados, o Distrito Federal e aos Municípios organizar o sistema público de saúde, de modo que sejam instituídas as políticas públicas que assegurem o acesso universal e igualitário com atendimento integral. A garantia constitucional de pleno acesso à saúde ainda está longe de ser concretizada. Isso se reflete no exponencial crescimento da chamada judicialização da saúde, consistente no ajuizamento de ações judiciais para que o Poder Judiciário assegure o acesso aos serviços de saúde negados administrativamente. A complexidade da normatização e da regulação, a falta de informações claras e a deficiência na gestão, tem dificultado a compreensão do Sistema Único de Saúde (SUS) pelos órgãos jurídicos, sobretudo pelos membros do Poder Judiciário, que os tem levado a cometer alguns equívocos, deferindo o acesso a serviços de saúde sem evidência científica comprovada, além de ordenar providências em descompasso com a regulação das políticas públicas instituídas, tumultuando ainda mais a gestão da saúde e causando um impacto deslocativo no orçamento. O art. 23, II da Constituição Federal que instituiu a competência comum da União, dos Estados, do Distrito Federal e dos Municípios para cuidar da saúde, tem levado os julgadores a desconsiderar as normas jurídicas legais e infra legais de repartição da competência e distribuição de atribuições entre os gestores, impondo indistintamente aos três entes federados a responsabilidade por qualquer ação e serviço de saúde. É necessário discutir os limites da universalidade de acesso e a integralidade do atendimento assim como a validade das normas de repartição de competência e a distribuição de atribuições entre os gestores.

Palavras chave: Constituição Federal. Garantia. Acesso. Saúde. SUS. Responsabilidade Solidária. Responsabilidade Subsidiária. Universalidade. Igualdade. Integralidade. Impacto Deslocativo do Orçamento. Repartição de Competência.
\end{abstract}

\section{Abstract}

Health is a fundamental human right recognized in the Brazilian Federal Constitution. It is about a everyone's right and the State's duty, fulfilling to the Union, to the States, to the Federal District and to the Municipalities to organize the public health system, in a way that are instituted the public politics that assure the universal and equal access with comprehensive care. The constitutional 

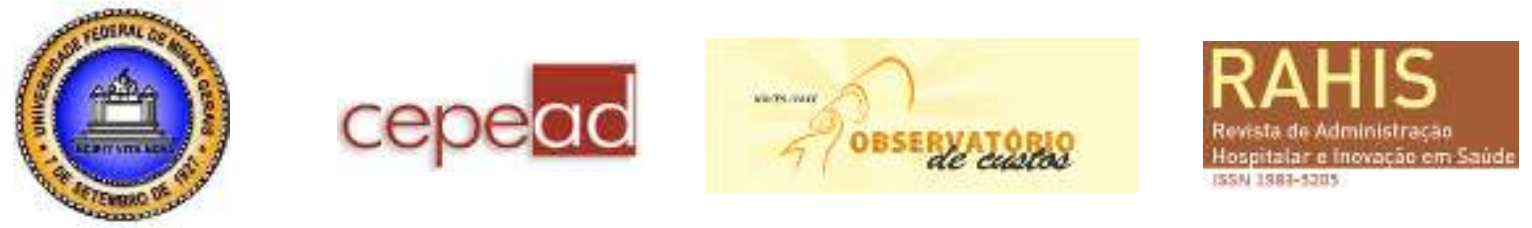

guarantee of full access to health is far of being concretized. This is shown on the exponential growth of the called the legalization of health, consistent on the filing of judicial actions so that the Juridical Power assure the access to the health services that are administratively denied. The complexity of standardization and regulation, the lack of clear information and the deficiency on the management has hampered on the comprehension of the Unique Health System by the juridical parts, especially by the members of the Juridical Power, which has taken them to commit some misconceptions, deferring the access to some health services without proved scientific evidence, besides order providences in mismatch with the regulation of the instituted public politics, rioting even more the management and causing a dislocative impact on the budget. The art. 23, from the Federal Constitution which instituted the common competence from the Union, the States, the Federal District and the Municipalities to take care of the health, has taken the judges to disregard the legal and infra legal juridical standards of repartition of the competence and distribution of assignments between the managers, imposing indistinctly to the three the responsibility for any action and health service. It's necessary to discuss the limits of the universality of access and the completeness of the care as the validity of the repartition standards of competence and the distribution of attribution between the managers.

Key words: Federal Constitution. Warranty. Access. Health. SUS. Joint Responsibility. Subsidiary responsibility. Universality. Equality. Completeness. Dislocative budget impact. Division of Competence

\section{Resumen}

La salud es un derecho humano fundamental reconocido en la Constitución de la República Federativa del Brasil. Es derecho y deber del Estado de todos, al servicio de la Unión, los Estados, el Distrito Federal y los municipios organizar el sistema de salud pública, a fin de que se establezcan políticas públicas que garanticen el acceso universal e igualitario a la atención integral. La garantía constitucional de acceso completo a la atención médica está todavía lejos de ser realidad. Esto se refleja en el crecimiento exponencial de la llamada legalización de salud, consistente en acciones legales para que el Poder Judicial garantiza el acceso a servicios de salud negados administrativamente. La complejidad de la normalización y la regulación, la falta de información clara y gestión de la discapacidad, ha dificultado la comprensión del Sistema Único de Salud (SUS) por los órganos judiciales, especialmente los miembros del poder judicial, lo que les ha llevado a cometer algunos errores, la concesión de acceso a la salud sin los servicios de pruebas científicas comprobadas, y las medidas de orden de paso con la regulación de la política pública establecida, alterando aún más la gestión de la salud y causar un impacto deslocativo sobre el presupuesto. El arte. 23, II de la Constitución Federal, que establece la responsabilidad común de la Unión, los Estados, el Distrito Federal y los municipios para el cuidado de la salud, ha llevado a los jueces hacer caso omiso de las normas jurídicas de derecho y la infraestructura legal de asignación de responsabilidades y distribución de tareas entre administradores, imponiendo de manera indiscriminada a la responsabilidad de tres agencias federales para cualquier acción y el servicio de salud. Es necesario discutir los límites de acceso universalidad e integralidad de la atención, así como la validez de las normas de asignación de competencia y la distribución de responsabilidades entre los directivos.

Palabras clave: Constitución Federal. Depósito. Acceso. Salud. SUS. Corresponsabilidad. Responsabilidad Subsidiaria. Universalidad. Igualdad. Integridad. Impacto Presupuesto Deslocativo. División de competencias. 

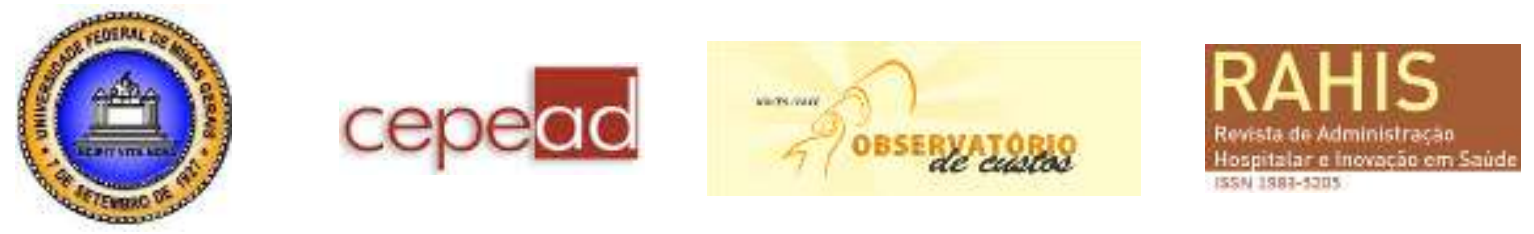

\section{Introdução}

A Constituição da Organização Mundial da Saúde - OMS define saúde como um estado de completo bem-estar físico, mental e social, e não consiste apenas na ausência de doença ou de enfermidade.

A Constituição brasileira de 1988 (CF) inseriu a saúde no capítulo dos direitos fundamentais, definindo-a como um direito social (art. $6^{\circ}$ ) como espécie de direitos humano fundamental. Do detalhamento constitucional do direito à saúde decorre a conclusão de que se trata de um direito humano fundamental que exige uma prestação positiva do "Estado" e da sociedade, ${ }^{1}$ a ser inserido nas políticas públicas. É um direito social de natureza pública e subjetiva, com característica híbrida, pois constitui ao mesmo tempo um direito individual e social.

A saúde também está contemplada na Constituição Federal como direito de todos e dever do Estado, a ser garantida mediante políticas públicas com acesso universal e igualitário que assegurem a promoção, proteção e recuperação, com o atendimento integral.

O Estado Brasileiro ainda está longe de assegurar a plenitude de acesso e tratamento integral à saúde. Isso se evidencia no exponencial crescimento de demandas judiciais por meio das quais a população tenta o acesso a tratamentos, internações, exames e medicamentos que lhe são negados administrativamente.

O Poder Judiciário tem sido protagonista em garantir o acesso aos serviços de saúde da população. A atuação proativa do Judiciário tem conduzido a um ativismo judicial para suprir as dificuldades administrativas e dar efetividade a essa garantia constitucional. Por seu turno, a falta de conhecimento mais apurado sobre a técnica médica e a regulação da saúde, somado à falta de uma assessoria especializada para os membros do Poder Judiciário, pode fomentar lides temerárias, facilitando o acesso a terapias "milagrosas" sem evidência científica.

Embora criticada a postura protagonista do Judiciário, a experiência mostra que tem havido a incorporação de novos produtos em saúde, especialmente daqueles medicamentos que são mais judicializados.

Embora as estatísticas disponíveis não sejam muito confiáveis, no último levantamento publicado, com dados do mês de junho de $2014,{ }^{2}$ o Conselho Nacional de Justiça - CNJ identificou, com base em informações prestadas pelos diversos Tribunais Estaduais e Federais, que estão em tramitação um total de $392.921^{3}$ processos, sendo 330.630 na Justiça Estadual e 62.291 na Justiça Federal. ${ }^{4}$

\footnotetext{
${ }^{1}$ LEDUR, José Felipe. Os direitos fundamentais sociais. Porto Alegre: Livraria do Advogado, 2009, p. 89.

2 Os dados estatísticos não são seguros porque as informações de vários Tribunais como é o caso dos Estados de São Paulo, Rio Grande do Sul, Ceará, do TRF-2 e TRF-3, entre outros, se referem a dados antigos, os mesmos fornecidos nos anos de 2010 e 211

3 http://www.cnj.jus.br/images/programas/forumdasaude/demandasnostribunais.forumSaude (acessado em $01.8 .2014)$

${ }^{4}$ Nesses dados não constam informações sobre os processos em tramitação na Justiça Estadual do Amazonas, Pernambuco e Paraíba.
} 

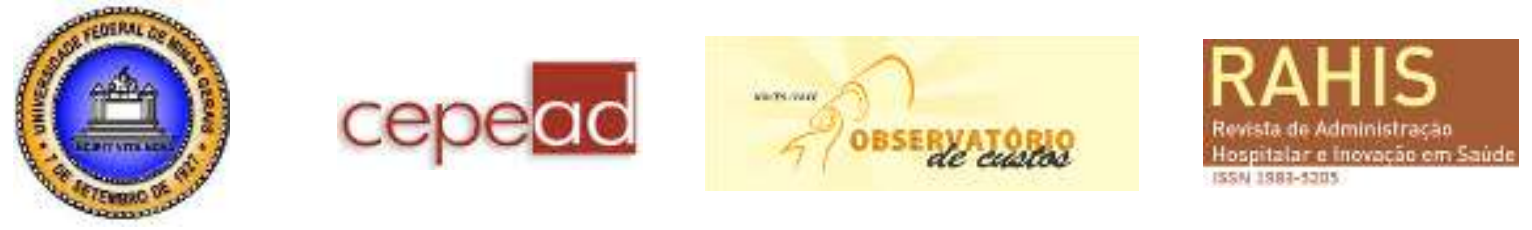

Uma questão que merece análise detida, em relação à qual o Poder Judiciário ainda não se pronunciou especificamente, diz respeito à validade das normas legais e infra legais de repartição da competência e distribuição de atribuições entre a União, os Estados, o Distrito Federal e os Municípios no que se refere as ações e serviços de saúde.

Não obstante a ausência de uma análise jurídica mais detida das normas infraconstitucionais (legais e infra legais) que distribuem responsabilidades e repartem competências entre os gestores, o Poder Judiciário, em sua maioria, ainda aplica de forma irrestrita a regra de solidariedade instituída no artigo 23, II, da Constituição Federal.

As decisões do Poder Judiciário, atribuindo a responsabilidade solidária e impondo aos três gestores idêntica responsabilidade pelo acesso à saúde, tem agravado ainda mais os problemas de gestão, sobretudo dos Municípios menores, porque sofrendo um impacto deslocativo no orçamento, ao são obrigados a desviar recursos para ações não planejadas, sem atentar que isso acarreta "ineficiência na prestação dos serviços de saúde, com a mobilização de recursos federais, estaduais e municipais para realizar as mesmas tarefas.". 5

No presente artigo pretende-se analisar a regulação do acesso à saúde, os desafios do sistema, os limites do acesso universal e igualitário com atendimento integral, assim como a identificação das normas que distribuem a responsabilidade, repartindo competências entre a União, os Estados, o Distrito Federal e os Municípios para prestar os serviços de saúde, atentando para a possível repercussão das ações judiciais no planejamento administrativo e operacionalização do SUS.

\section{A regulação constitucional do acesso à saúde}

O direito à saúde mereceu destaque especial na Constituição Federal qualificando-a como social (art. $6^{\circ}$ ), uma espécie de direito humano fundamental. Instituiu a responsabilidade comum da União, dos Estados, do Distrito Federal e dos Municípios pela implementação das políticas públicas (CF, art. 23, II), inserindo-a como um direito de todos e dever do Estado, a ser garantido mediante políticas públicas com acesso universal e igualitário (art. 196), com atendimento integral (art. 198, II). Essas garantias foram todas reafirmadas pelo art. $2^{\circ}$ da Lei Orgânica da Saúde (Lei nº 8.080/90).

Além de inserir a saúde como um direito social considerando-se um direito humano fundamental, a Constituição Federal avançou, introduzindo disposições expressas de garantia do acesso universal e igualitário. Orienta a organização da saúde pública numa rede regionalizada, hierarquizada e descentralizada, constituída de um sistema único, organizado de forma descentralizada, com direção única "em cada esfera de governo", financiada com recursos do orçamento da seguridade social, da União, dos Estados, do Distrito Federal e dos Municípios, tudo para propiciar o atendimento integral.

\footnotetext{
${ }^{5}$ BARROSO, Luís Roberto. Da falta de efetividade à judicialização excessiva: direito à saúde, fornecimento gratuito de medicamentos e parâmetros para a atuação judicial. Revista de Jurisprudência Mineira, a. 60, n. 188, Belo Horizonte, jan./mar. 2009.
} 

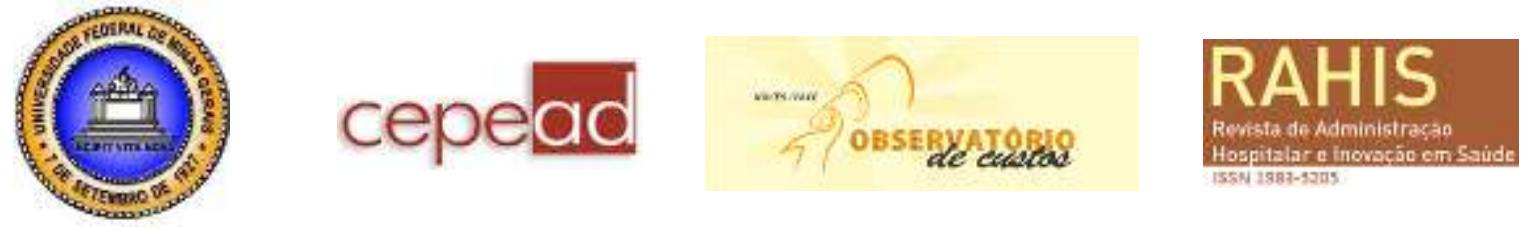

O sistema normativo brasileiro também parametriza os recursos mínimos que devem ser aplicados nos serviços de saúde. Aos Estados-membros e ao Distrito Federal ${ }^{6}$ é imposta a aplicação em saúde de recursos mínimos de 12\%, e aos Municípios de 15\%, enquanto a União não tem percentual mínimo de gastos com saúde, contudo seus gastos se sujeitam à variação do PIB, com a instituição da cláusula de não regresso a impedir a redução nominal dos gastos (ADCT, art. 77, e LC n ${ }^{\circ} 141 / 2012$, arts. $5^{\circ}, 6^{\circ}$ e $7^{\circ}$ ).

A Carta da República impôs aos Municípios a responsabilidade de prestar diretamente os serviços de atendimento à saúde, embora devam fazê-lo em cooperação técnica e financeira da União e dos Estados (CF, art. 30, VII).

A responsabilidade constitucional imposta aos Municípios pela prestação de serviços de saúde é de eficácia plena, ${ }^{7}$ independente de ser instituída a cooperação técnica e financeira da União e dos Estados. Os Municípios acabam sendo os mais sacrificados em seus orçamentos, tanto que despendem, em média, mais de $22 \%$ da sua receita orçamentária com saúde, embora Gilson Carvalho informe que há estudos do ano de 2011 que apontem gastos da ordem de $21,5 \% .^{8}$

Os Estados têm limitado os gastos com saúde ao piso de 12\%, enquanto os dispêndios da União são de aproximadamente $7 \%$ da receita orçamentária líquida. Os gastos dos governos no Brasil com saúde representam aproximadamente 3,9\% do Produto Interno Bruto. ${ }^{9}$

Na proposta orçamentária do ano de 2014 a União do ano de 2014, destinou para os gastos com saúde o equivalente a 100,3 bilhões, já para o ano de 2015 a destinação é de aproximadamente 109,2 bilhões, para um orçamento de 1,235 trilhões ${ }^{10}$. Pode parecer que estão sendo programados gastos com saúde que se aproximam da ordem de $10 \%$ da receita líquida, contudo, não é bem assim. A impressão é falsa por duas razões: a) o orçamento não costuma ser executado integralmente; b) não há o destaque, no total das despesas orçadas, daqueles gastos que não podem ser consideradas como despesas com saúde, como é o caso das aposentadorias e pensões de militares, além de gastos com saúde das estatais, descumprindo o que prevê o art. $4^{\circ}$ da Lei Complementar $n^{\circ}$ 141/2012 e distorcendo o que efetivamente é gasto com saúde.

A responsabilidade do Município como executor direto das ações de saúde $(\mathrm{CF}$, art. 30, VII) não exclui a responsabilidade subsidiária dos demais gestores, porque a execução depende da cooperação técnica e financeira da União e do Estado. Aliás, existe a responsabilidade comum institucional prevista no art. 23, II da Constituição Federal, que

\footnotetext{
6 Nunca é demais lembrar que, na federação brasileira, o Distrito Federal condensa competências dos Estados-membros e dos Municípios.

${ }^{7}$ As normas constitucionais de eficácia plena podem se definidas como sendo aquelas que produzem ou tem a possibilidade de produzir de plano os seus efeitos, independente da superveniência de normas infraconstitucionais regulamentadoras para a sua instituição.

${ }^{8}$.http://apsredes.org/site2012/wp-content/uploads/2012/08/GASTO-P\%C3\%9ABLICO-MUNICIPAL-EM-SA\% C3\% 9ADE-2011-GILSON-2. (acessado em 07.09.2014)

${ }^{9} \mathrm{http}: / / \mathrm{www}$. ipea.gov.br/portal/index.php (acessado em 26.08.14)

${ }^{10} \mathrm{http}: / /$ www2.camara.leg.br/camaranoticias/noticias/ADMINISTRACAO-PUBLICA/473527-ORCAMENTO-

DE-2015 (acessado em 06.09.2014)
} 

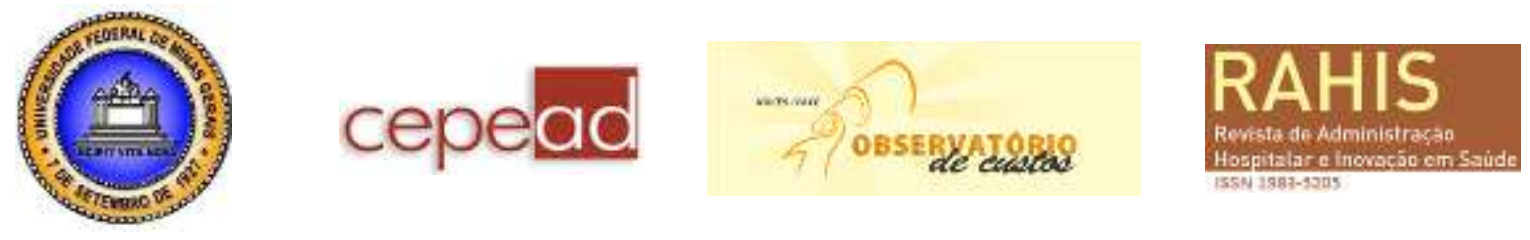

somente será fracionada quando pactuadas e implantados programas específicos de atendimento à população. Também, por imperativo constitucional, o financiamento do sistema de saúde é da União, dos Estados, do Distrito Federal e dos Municípios (CF, art. 198, § 1º).

\section{O acesso universal e igualitário}

Como visto, a saúde é um direito de todos e dever do Estado, devendo ser garantido o acesso universal e igualitário, assegurado mediante políticas públicas (sociais e econômicas) com prevalência para as ações que visem à redução do risco de doenças e de outros agravos, tanto para a promoção, proteção e recuperação.

A expressão acesso universal e igualitário significa dizer que a saúde deve ser assegurada a todos, com acesso e tratamento isonômicos, sem preconceito ou privilégio de qualquer natureza, inclusive financeiro. A universalidade de acesso à saúde se insere no contexto constitucional como um direito social para o exercício da cidadania plena.

Em seu discurso de posse como Diretora da Organização Pan-Americana da Saúde (OPAS), proferido em 31.01.2013, Carissa Etienne estabeleceu os pilares norteadores do acesso universal à saúde como sendo, o acesso do indivíduo à prevenção, promoção, diagnóstico, tratamento e acompanhamento, apoio às políticas nacionais, acesso à tecnologia e medicamentos e fortalecimento dos sistemas de saúde baseados na atenção primária. ${ }^{11}$

Acesso igualitário significa dizer que os serviços de saúde devem ser oferecidos de forma isonômica a todos, porque se trata de um direito social e não assistencial, alcançando a coletividade. Isso também significa dizer que o acesso à saúde deve ser garantido de forma igualitária, de modo que não pode haver tratamento discriminatório para o acesso universal e sequer quanto à condição financeira do usuário (rico ou pobre).

Parece que o entendimento de Ricardo Lobo Torres é equivocado, ao entender que o acesso à saúde pública se destina aos pobres, ponderando que somente as atividades preventivas geram o direito ao atendimento integral e gratuito, beneficiando ricos e pobres. Quanto à medicina curativa, entende que deva ser remunerada, exceto quando se tratasse de indigentes e pobres, que têm o direito ao mínimo de saúde sem qualquer contraprestação financeira, posto que se trata de direito tocado pelos interesses fundamentais. ${ }^{12}$

José Afonso da Silva, ensina diferentemente, que a igualdade da saúde visa o atendimento a todos, independentemente de sua situação econômica, sob pena de não ter muito valor sua consignação em normas constitucionais. ${ }^{13}$

Como a saúde é um direito social fundamental não cabem distinções de classe social quanto ao seu acesso, ou, como também acentua José Felipe Ledur:

\footnotetext{
11 http://www.paho.org/bra/index.php?option=com_content\&view=article\&id=3142 Itemid (acessado em 20.07.14)

12 TORRES, Ricardo Lobo. O direito ao mínimo existencial. Rio de Janeiro: Renovar, 2009. p. 245.

${ }^{13}$ SILVA, José Afonso da. Comentário Contextual à Constituição. $3^{\mathrm{a}}$ ed. São Paulo: Malheiros, 2007. p. 767.
} 

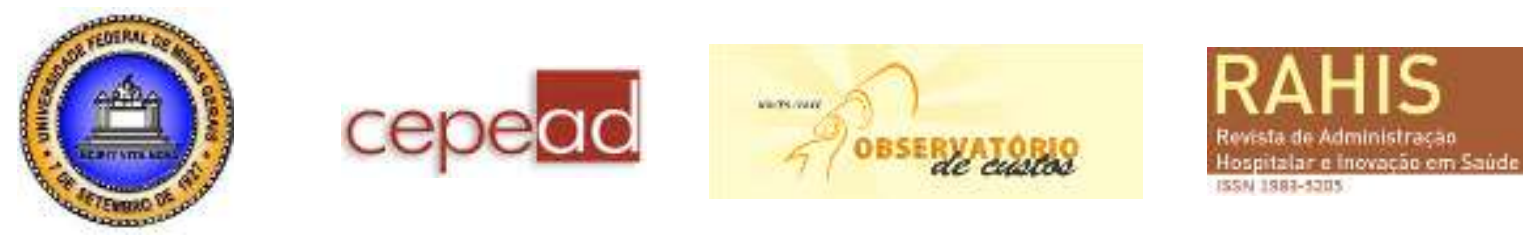

Os direitos sociais reconhecidos no art. $6^{\circ}$ formulados em termos gerais, em nível de princípios, e pertencerem às pessoas como membros da comunidade política e jurídica, eles se dirigem a todos, ou seja, não correspondem a uma categoria específica de titulares de direitos fundamentais. ${ }^{14}$

Ingo Wolfgang Sarlet acentua que a Constituição Federal atribui a titularidade do direito à saúde a toda e qualquer pessoa, inclusive ao estrangeiro. ${ }^{15}$

Gilmar de Assis, Promotor de Justiça de Minas Gerais, empenhado profissionalmente pela melhoria da saúde pública, pondera que "eventual interpretação judicial restritiva do princípio constitucional da universalidade do acesso às ações e serviços de saúde é inconstitucional", sob o entendimento de que se encontra atado ao princípio da dignidade da pessoa humana. ${ }^{16}$

Destarte, à expressão acesso universal e igualitário deve ser dada a interpretação mais ampla possível, de modo que seja assegurado o acesso à saúde, preventiva ou curativa, a todos, à universalidade de pessoas, sem privilégio, discriminação, não permitindo a instituição de políticas públicas baseadas no critério da hipossuficiência, ou seja, deve ser assegurado tratamento igual e garantido o acesso tanto ao pobre, quanto ao rico.

Importa lembrar que, embora por imperativo constitucional esteja garantido o acesso universal e igualitário, inclusive para ações individuais, deve ser dada prevalência para os tratamentos oferecidos nas políticas públicas, sobretudo para aquelas de natureza preventiva e de caráter coletivo, destinadas à redução do risco de doenças e de outros agravos.

Está evidenciada a preocupação constitucional com a atenção básica, porque este é o meio pelo qual se reduz o risco de doenças e a evolução dos seus agravos.

\section{A integralidade do atendimento}

Sendo a saúde um direito social existe divergência doutrinária se se constitui um direito público subjetivo ou de natureza apenas programática. A maioria da doutrina parte do entendimento de que o direito à saúde enquadra-se no mínimo existêncial, ${ }^{17}$ de modo que o

\footnotetext{
${ }^{14}$ LEDUR, José Felipe. Os direitos fundamentais sociais. Porto Alegre: Livraria do Advogado, 2009. p. 82.

${ }^{15}$ SARLET, Ingo Wolfgang. A eficácia dos direitos fundamentais. $11^{\mathrm{a}} \mathrm{ed}$. Porto Alegre: Livraria do Advogado, 2012. p. 215.

16 ASSIS, Gilmar de. SUS para todos: Breves reflexões jurídico-sociais. Avanços e desafios. In: Saúde: ALMEIDA, Gregório Assagra de; SOARES Jr., Jarbas; ASSIS, Gilmar de (coord). Belo Horizonte: Del Rey, 2013, p. 87.

${ }^{17} \mathrm{O}$ mínimo existencial constitui um direito às condições mínimas de existência humana digna, que não pode ser objeto de intervenção do Estado e que ainda exige prestações estatais positivas. (TORRES, Op. cit., p. 8).
} 

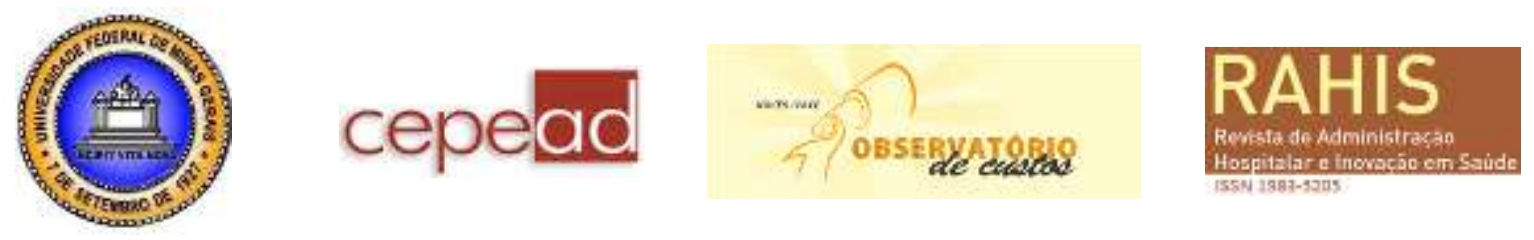

Poder Público tem obrigação de colocar à disposição das pessoas um conjunto de ações mínimas dentro do mínimo existencial. ${ }^{18}$

O art. 198, II, da Constituição Federal introduziu entre as suas diretrizes o atendimento integral à saúde, priorizando as atividades preventivas, sem prejuízo dos serviços assistenciais.

A integralidade é tratada na Constituição Federal como uma diretriz para a organização do sistema único, enquanto o art. $7^{\circ}$, I, da Lei 8.080/90 (Lei Orgânica da Saúde) a eleva à categoria de princípio orientador do Sistema Único de Saúde.

A especificidade e o detalhamento das disposições constitucionais que asseguram o acesso à saúde pública evidenciam o efeito concreto quanto à integralidade do atendimento.

Embora o art. 197 da Constituição Federal tenha delegado a regulação da saúde para a lei, não existe a possibilidade de as normas infraconstitucionais restringirem a garantia constitucional, sob o risco de fraudarem as expectativas introduzidas no texto constitucional, como acentuou o Ministro Celso Mello.

O caráter programático da regra inscrita no art. 196 da Carta Política - que tem por destinatários todos os entes políticos que compõem, no plano institucional, a organização federativa do Estado brasileiro não pode converter-se em promessa constitucional inconsequente, sob pena de o Poder Público, fraudando justas expectativas nele depositadas pela coletividade, substituir, de maneira ilegítima, o cumprimento de seu impostergável dever, por um gesto irresponsável de infidelidade governamental ao que determina a própria Lei Fundamental do Estado. ${ }^{19}$

A integralidade como diretriz constitucional prioriza a atividade preventiva por meio das políticas públicas, contudo não exclui os tratamentos individuais, de natureza preventiva ou curativa. Ao usuário deve ser assegurado o acesso a produtos não contemplados pelas políticas públicas, desde que provada a necessidade peculiar de produtos ou procedimentos diferenciados, desde que demonstrado que acesso diferencia é eficaz, eficiente, efetivo e seguro. Também deve ser demonstrado que os produtos oferecidos dentro dos protocolos do SUS são atendem às necessidades peculiares da enfermidade daquele usuário individual.

Sobre a prevalência do tratamento oferecido pelo SUS, o Ministro Gilmar Mendes, do Supremo Tribunal Federal, acentuou em seu voto, ao julgar a Suspensão de Tutela Antecipada - STA/CE no 175, que em geral, deverá ser privilegiado o tratamento fornecido pelo SUS em detrimento de opção diversa escolhida pelo paciente, sempre que não for comprovada a ineficácia ou a impropriedade da política de saúde existente. ${ }^{20}$

\footnotetext{
${ }^{18}$ BARCELlOS, Ana Paula de. A eficácia jurídica dos princípios constitucionais. $3^{\mathrm{a}}$ ed. Rio de Janeiro: Renovar, 2011. p. 320.

${ }^{19}$ BRASIL - STF - RE-AGR No 393175/RS, 2a TURMA, REL. MIN. CELSO DE MELLO, DJ 02-02-2007

${ }^{20}$. Idem: STA-AgR 175/CE.
} 

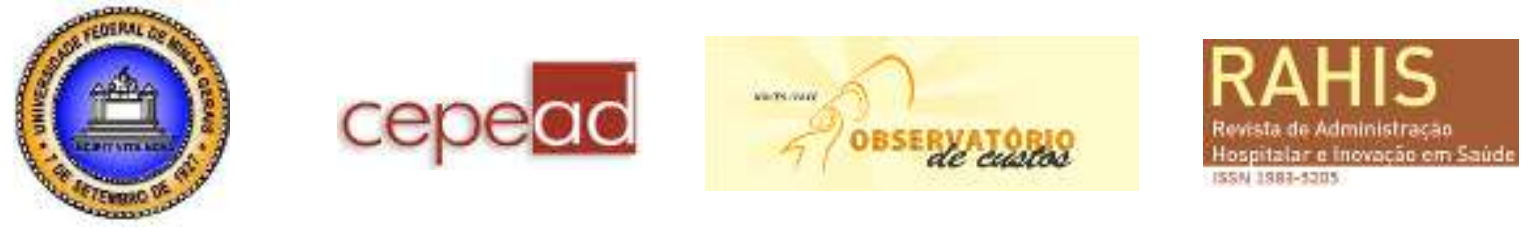

Efetivamente, não há como determinar ao poder publico conceder o acesso a novos procedimentos em detrimento do erário, sem perquirir previamente a imprescindibilidade de produtos diversos àqueles oferecidos nos SUS, de modo que cabe ao usuário o ônus da prova da ineficácia daquilo que estiver sendo oferecido.

Embora se deva admitir, como afirmado por Lenir dos Santos, que o direito à integralidade da assistência terapêutica não pode ser aleatória e ficar sob a total independência do cidadão, ${ }^{21}$ não há como negar que, em casos especiais, quando as terapias oferecidas pelos serviços de saúde sejam ineficazes, permita-se o acesso a terapias não incorporadas, desde que reconhecidas pela medicina baseada em evidências.

A Lei 12.401 de 28.4.2011 introduziu algumas alterações na Lei 80.080 de 19.9.1990 (Lei Orgânica da Saúde - LOS), regulando os procedimentos para a incorporação de novas tecnologias no SUS. Define as regras disciplinadoras da cobertura integral e padronizando a incorporação de novas tecnologias em saúde (LOS, art. 19-M). Trata-se de alteração para fixar os limites da integralidade, a fim de conter abusos. Contudo, a leitura que os tribunais brasileiros fazem é de que a integralidade assegurada constitucionalmente não permite que se fixem protocolos restritivos da integralidade. Aliás, o art. 19-P da própria LOS prevê a dispensação excepcional na falta de protocolo clínico ou de diretriz terapêutica.

As alterações legislativas para regular a integralidade de atendimento da saúde criaram uma regra de cobertura integral, dando a entender que o atendimento integral ficaria limitado aos produtos e serviços oferecidos nos protocolos de cobertura das políticas públicas de saúde.

Ocorre que a Constituição brasileira optou por um sistema universal de saúde, de modo que o atendimento não pode se restringir às políticas instituídas. Embora devam ser privilegiados os produtos e serviços constantes nos protocolos clínicos do SUS, não há como negar o acesso a outras terapias, desde que o tratamento diferente esteja reconhecido na medicina baseada em evidência e haja demonstração de que aquele ofercido pelo SUS é ineficaz ou insuficiente.

O parágrafo único do art. $19-\mathrm{O}$ da Lei 8.080/90 inclui, dentre os critérios para a incorporação de novos benefícios, o custo-efetividade, ${ }^{22}$ o que, em tese, autoriza restringir a integralidade em razão do custo, mas, essa limitação padece de vício de constitucionalidade, porque o atendimento integral está assegurado na CF. Embora os direitos sociais se sujeitem aos limites financeiros do "Estado", somente prova cabal permite interpretação restritiva, de modo que além de invocar a cláusula da reserva do possível cumpre ao poder público o ônus da prova da absoluta incapacidade financeira.

Parece temerário autorizar ao Ministério da Saúde limitar a integralidade de atendimento à saúde aos protocolos por ele instituídos. Seria o mesmo que admitir a mitigação do direito humano fundamental à saúde reconhecido constitucionalmente, porque

\footnotetext{
${ }^{21}$ SANTOS, Lenir dos. Direito à saúde e sistema único de saúde: Conceito e atribuições. O que são ações e serviços de saúde (in) Direito da saúde no Brasil. Campinas: Saberes, 2010. p. 166

${ }^{22}$ Lei $n^{\circ}$ 8.080/90, art. 19 - Parágrafo único. Em qualquer caso, os medicamentos ou produtos de que trata o caput deste artigo serão aqueles avaliados quanto à sua eficácia, segurança, efetividade e custo-efetividade para as diferentes fases evolutivas da doença ou do agravo à saúde de que trata o protocolo.
} 

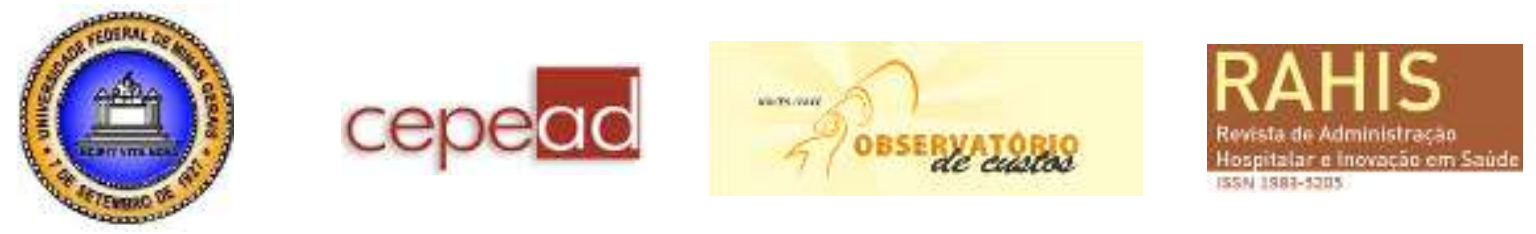

estar-se-ia permitindo que a conveniências políticas e morais de governo definam os limites da integralidade nos serviços de saúde, limitando-a ao que estivesse definido no pacote de cobertura integral, mitigando a promessa constitucional.

Não há como se afastar da realidade de que os recursos públicos são finitos e que pode haver limitações econômicas para o acesso a todo e qualquer produto de saúde, permitindo-se aos gestores invocar a cláusula da reserva do possível. Contudo, como a Constituição Federal assegura o acesso universal e o atendimento integral, a falta de cobertura nos protocolos clínicos para produto da mesma natureza ou similares, necessários a qualquer tratamento, quando baseado em evidência científica, viola a garantia do acesso ao direito humano fundamental que é a saúde (art. $6^{\circ}$ ), cabendo ao gestor a prova da incapacidade financeira para suportar os custos do tratamento reclamado.

Portanto, a alegação da incapacidade financeira não pode ser mera retórica jurídica da falta de previsão orçamentária. Ocorre que, embora o orçamento seja aprovado pelo Legislativo, a proposta orçamentária é elaborada dentro da discricionariedade do Executivo, que, em tese, poderá a restringir as verbas para a saúde. Por isso, invocada a cláusula da reserva do possível é necessário demonstrar a efetiva incapacidade econômica do ente e não apenas a falta de rubrica orçamentária.

$\mathrm{Na}$ garantida da integralidade de tratamento da saúde sempre devem sempre prestigiadas as políticas públicas, mas, sem afastar a possibilidade do acesso fora dos protocolos clínicos, para casos excepcionais não contemplados, desde provada a peculiaridade da enfermidade, e de que os produtos oferecidos pelo SUS são ineficazes para preservar a vida digna.

\section{A medicina baseada em evidência}

O Estado Brasileiro optou pela saúde baseada em evidência, o que foi incorporado no art. 19-O, parágrafo único, da Lei 8.080/90, de modo que a integralidade de atendimento prevista constitucionalmente não assegura o acesso a serviços de saúde sem evidência científica, não se admitindo, por exemplo, o acesso produtos que ainda estejam em fase experimental.

No julgamento da Suspensão de Tutela Antecipada - STA no $175-C E,{ }^{23}$ o Ministro Gilmar Mendes pontuou que o SUS filiou-se à corrente da medicina com base em evidências. ${ }^{24}$ Assim, o tratamento deve ser realizado de acordo com o estágio atual da ciência médica, não sendo razoável a utilização de recursos públicos para patrocinar serviços ou tratamentos experimentais, porque isso constituiria num inadmissível modo de patrocínio público de experiências da indústria farmacêutica.

\footnotetext{
23 Trata-se de pedido de medicamento de componente especializado excepcional fora dos protocolos clínicos, consistente no medicamento REBIF 44Mg (Betainterferona), necessário para o tratamento de Esclerose Múltipla. ${ }^{24}$ BRASIL. STF. STA-AgR 175/CE. Agravo Regimental em Suspensão de Tutela Antecipada. Relator: Ministro Gilmar Mendes (presidente). Julgamento: 17 mar. 2010. Publicação DJ 30 abr. 2010.
} 

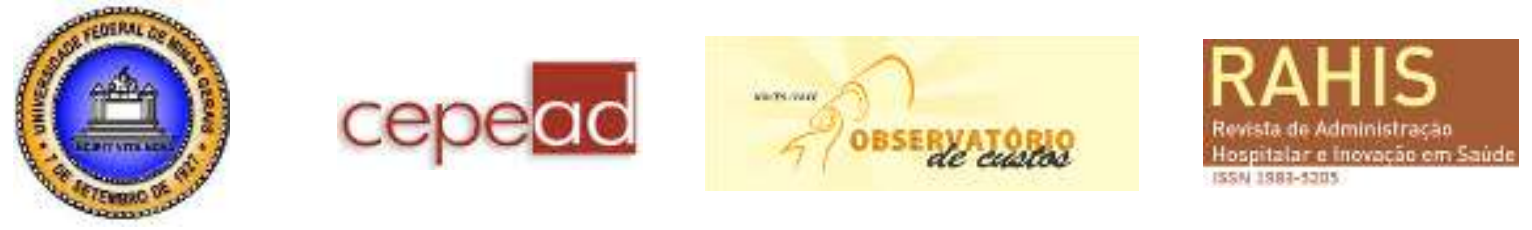

Lenir dos Santos acentua que a indústria, muitas vezes, é mais da doença que da cura e que nem sempre há dignidade em morrer no hospital, na UTI, cheio de tubos, longe do afeto familiar, em nome de uma falsa ou suposta possibilidade de prolongamento da vida. ${ }^{25}$ Por isso, judicializado o acesso a produtos diferentes daqueles oferecidos nas políticas públicas, deve estar provado que o tratamento diferenciado é capaz de oferecer um mínimo de consciência e lucidez com o mínimo de sofrimento.

Não se mostra plausível despender dinheiro público para custear tratamentos milagrosos, à margem da medicina baseada em evidência.

\section{O protagonismo do Poder Judiciário e a repercussão na gestão pública}

No panorama de saúde, o Poder Judiciário tem sido protagonista, adotando uma postura proativa para garantir o acesso às ações e serviços de saúde, a fím de assegurar o universal e a integralidade de atendimento. Nessa atuação inexiste interferência da discricionariedade do gestor ou violação da independência dos poderes, porque a atuação judicial se restringe a reparar a violação de um direito constitucional à saúde.

O ativismo judicial, muitas vezes criticado, na verdade constitui uma deliberada expansão do papel do Judiciário, mediante ouso da interpretação constitucional para suprir lacunas, sanar omissões legislativas ou determinar políticas públicas quando ausentes ou ineficientes, ${ }^{26}$ o que significa dizer que sua atuação se restringe ao cumprimento da sua missão constitucional de reparar qualquer lesão ou ameaça a direito, sobretudo quando há omissão do Poder Público.

Para Lenio Streck afirma que "o Poder Judiciário não pode assumir uma postura passiva diante da sociedade", acentuando que deve ter "uma atuação que leve em conta a perspectiva de que os direitos construídos democraticamente - e postos na Constituição - têm precedência mesmo contra textos legislativos produzidos por maiorias eventuais", ${ }^{27}$ o que significa dizer que a norma infraconstitucional não pode limitar o acesso à saúdes.

CE:

O Supremo Tribunal Federal (STF) deixou assentado no julgamento da STA $\mathrm{n}^{\circ}$ 175-

Parece certo que a inexistência de Protocolo Clínico no SUS não pode significar violação ao princípio da integralidade do sistema, nem justificar a diferença entre as opções acessíveis aos usuários da rede pública e as disponíveis aos usuários da rede privada. Nesses casos, a omissão administrativa no tratamento de determinada patologia poderá ser objeto de impugnação judicial, tanto por ações individuais como coletivas. No entanto, é imprescindível que haja instrução processual,

\footnotetext{
${ }^{25}$ SANTOS, Lenir (Org) Direito à saúde e Sistema Único de Saúde: conceito e atribuições. O que são ações e serviços de saúde. In: Direito da Saúde no Brasil. Campinas: Saberes, 2010, p. 170.

${ }^{26}$ BARROSO, Luís Roberto. O novo direito constitucional brasileiro. Belo Horizonte: Fórum, 2014. p. 40

${ }^{27}$ STRECK, Lenio Luiz. Jurisdição constitucional e decisão jurídica. 4a ed. São Paulo: RT, 2013. p. 178.
} 

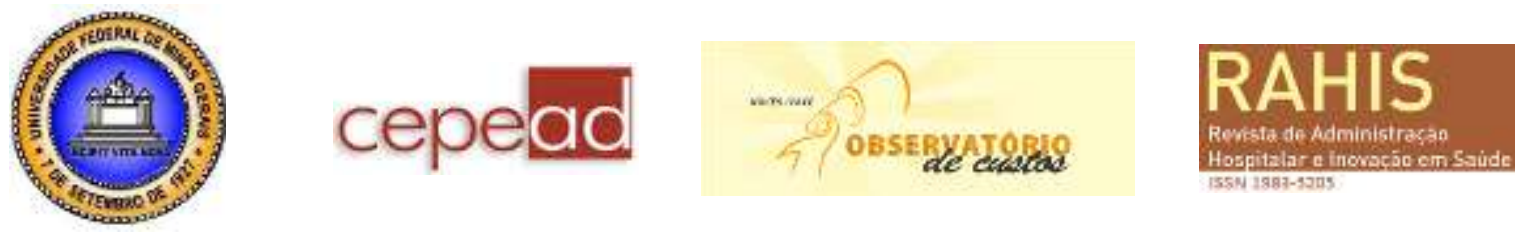

com ampla produção de provas, o que poderá configurar-se um obstáculo à concessão de medida cautelar.

Deve ser admitido, em decorrência da falta de conhecimento acerca de regulação da saúde e da medicina, algumas decisões judiciais não se revestem da melhor técnica, razão pela qual é imperioso que todos os Tribunais disponibilizem aos magistrados instrumentos de apoio técnico/científico de evidência médica para uma melhor qualificação das decisões, sobretudo das liminares, como, aliás, sugere o CNJ nas Recomendações $n^{\circ}$ 31/2010 e $36 / 2011$.

A assessoria técnica aos julgadores evita que caiam nas armadilhas dos argumentos sentimentais que podem levar a decisões equivocadas, assegurando o acesso a produtos com pouco ou nenhum embasamento cientifico.

A técnica processual exige que as partes instruam as suas demandas com os documentos destinados a provar o fato constitutivo do seu direito, de modo que nas demandas sobre saúde cabe ao autor o ônus da prova sobre a necessidade de acesso a produto diverso daquele oferecido pelo sistema de saúde, bem como da evidência médico-científica daquilo que se pretende e que não é oferecido pelo SUS, nem na forma similar. Grande parte dos pedidos liminares é fundamentada na necessidade premente, com o prenúncio da morte caso não deferida a pretensão. Sensibilizados, os julgadores acabam deferindo a liminar que, por vezes, não está embasada em evidência científica. Isso resulta muitas vezes, no dispêndio desnecessário de volumosas importâncias do erário para atender aventuras jurídicas baseadas em "receitas mágicas" com promessa de "curas milagrosas", sem qualquer evidência científica. O Poder Judiciário não pode se prestar a isso.

Embora não se possa mitigar a integralidade de atendimento à saúde, o Judiciário deve ficar atento à boa técnica jurídica, observando o caráter substitutivo da jurisdição, de modo que as decisões sejam proferidas com imparcialidade, sem passionalidade e baseadas em evidência científica.

Como destaca o Desembargador Osvaldo Firmo, o julgador não pode se pautar por uma técnica de empatia, colocando-se no lugar do pleiteante, ou neste fazendo confundir a pessoa de um ente parental muito próximo (germinante), ${ }^{28}$ ou ainda, como ensina Elizabeth Kübler Ross, é necessário compreender que as pessoas também morrem de causas naturais e de idade avançada, ${ }^{29}$ de modo que a morte não é um fato anormal.

Muitas vezes os familiares insistem na preservação da vida a qualquer custo, mesmo para pacientes com doenças crônicas num quadro de irreversibilidade. O magistrado deve ficar atento para não se envolver nas paixões dos familiares, confundindo tratamento integral com o acesso a procedimentos "milagrosos" sem evidência científica.

Como já afirmado, somente se sustenta na boa técnica jurídica o acesso a medicamentos e procedimentos fora daqueles ofertados pelo serviço de saúde quando os

\footnotetext{
${ }^{28}$ FIRMO, Osvaldo Oliveira Araújo. Direito à Saúde: Reflexão sobre a ética da decisão judicial. In: Revista do Instituto dos Magistrados do Ceará. Ano 14, no 29/30 (jan./dez.). Fortaleza: 2011. p. 296.

${ }^{29}$ ROSS, Elisabeth Kübler. Sobre a morte e o morrer. São Paulo: Martins Fontes, 2012, p. 06.
} 

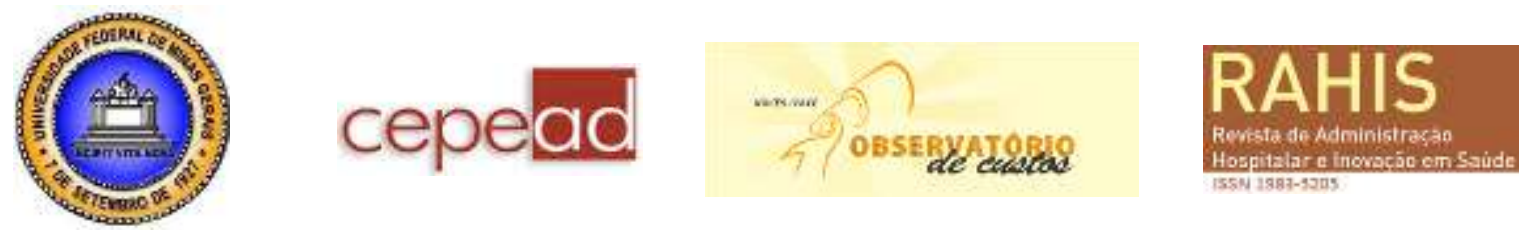

disponibilizados forem ineficazes e aqueles pretendidos estejam fundados em evidência científica, pois, como pondera Canotilho, "as normas jurídicas não são declarações de amor". ${ }^{30}$

$\mathrm{Na}$ tentativa de evitar as decisões apaixonadas, o $\mathrm{CNJ}$ editou as já referidas Recomendações $n^{\circ} 31 / 2010$ e $n^{\circ} 36 / 2011$, sugerindo aos Tribunais a celebração de convênios com o objetivo de oferecer apoio técnico aos magistrados na formação de um juízo de valor quanto à apreciação das questões clínicas apresentadas pelas partes, sobretudo sobre a evidência científica de que estiver sendo reclamado.

O Tribunal de Justiça de Minas Gerais celebrou parceria com a Secretaria Estadual da Saúde, que culminou na contratação do Núcleo de Avaliação de Tecnologias em Saúde NATS, vinculado ao Hospital das Clínicas, que elabora notas técnicas de evidência científica para o apoio aos magistrados. Antes de decidir pedidos de concessão de liminar, o julgador, de primeiro ou de segundo graus pode requisitar, eletronicamente, nota técnica de evidência científica do produto reclamado. As respostas fornecidas, em prazo que varia de 24 a 72 horas, trazem informações da evidência científica, a sua oferta ou não pelo SUS, ou sobre a existência de produto com eficácia terapêutica similar.

Em que pesem as críticas à atuação protagonista e proativa do Poder Judiciário, a experiência demonstra, no entanto, que as decisões judiciais reiteradas para garantir o acesso a novos produtos têm servido de ensejo para a análise da incorporação de novas tecnologias ao sistema público de saúde.

\section{O financiamento da saúde}

O art. 198 da Constituição Federal fixa as diretrizes para a organização da saúde, estabelecendo que as ações e serviços públicos de saúde devem integrar uma rede regionalizada e hierarquizada, que constitui o SUS, tudo a ser financiado com recursos do orçamento da seguridade social, da União, dos Estados, do Distrito Federal e dos Municípios.

A Lei Complementar $n^{\circ} 141$, de 13 de janeiro de 2012, regulamenta o $\S 3^{\circ}$ do art. 198 da Constituição Federal, fixando os valores mínimos a serem aplicados anualmente pela União, Estados-membros, Distrito Federal e Municípios em ações e serviços públicos de saúde, além de estabelecer critérios de rateio dos recursos de transferências para a saúde, assim como as normas de fiscalização, avaliação e controle das despesas com saúde nas três esferas de governo.

As regras introduzidas nos artigos $3^{\circ}$ e $4^{\circ}$ da Lei Complementar $n^{\circ} 141 / 12$ especificam os gastos que podem ser contabilizados como despesas com saúde. Trata-se de uma tentativa para impedir as distorções, com o lançamento de despesas de natureza diversa, como se constituíssem gastos com saúde.

\footnotetext{
${ }^{30}$ CANOTILHO, J.J. Gomes. O direito dos pobres no activismo judiciário. In: Direitos Fundamentais Sociais. CANOTILHO,J.J. Gomes; CORREIA, Marcus Orione Gonçalves; CORREIA, Érica Paula Barcha. (coord.) São Paulo: Saraiva, 2010. p. 35.
} 

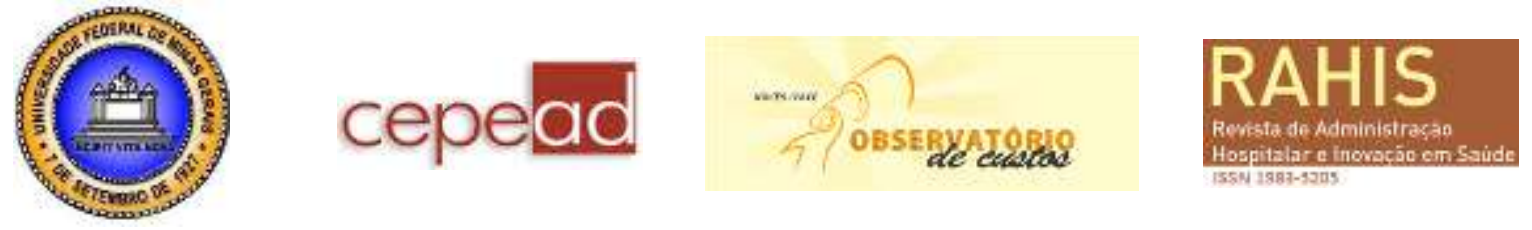

O legislador complementar não resistiu à pressão do Poder Executivo e deixou de fixar um percentual mínimo de gastos com a saúde para União. Manteve o percentual mínimo de 12\% para os Estados e de 15\% para os Municípios, que já constavam no art. 77 dos Atos de Disposições Constitucionais Transitórias. Quanto à União, existe apenas a cláusula de não regresso, de modo que não pode haver redução nominal dos gastos com saúde.

A saúde está subfinanciada, é fato. Os Municípios são os principais sacrificados, tanto que, em média, despendem $22 \%$ da sua receita líquida com ações e serviços de saúde. Os Estados-membros dificilmente ultrapassam o patamar de $12 \%$. A União, por seu turno, despende de 7\% a 7,5\% da sua receita líquida em saúde, tendo incluído no orçamento de 2013 o total de 85,70 bilhões, para 2014, 98,03 bilhões, e na proposta de 2015 aproximadamente 109,2 bilhões, para uma proposta orçamentária de 1,235 trilhões. ${ }^{31}$ As despesas dos Municípios aumentaram, enquanto o percentual da União no financiamento da saúde tem-se reduzido.

As estatísticas demonstram que a União vem diminuindo a sua participação nos gastos com saúde que em 1980, antes da declaração constitucional do direito à saúde do cidadão e dever do estado assumido pelas três esferas de governo era responsável pelo financiamento da saúde em cerca de $75 \%$, chegando ao ano de 2011 como sendo responsável por apenas $47 \%$ dos gastos em saúde. ${ }^{32}$

Embora haja necessidade de aumentar o financiamento da saúde, isso, por si só, não resolverá os problemas de ineficiência dos serviços, antes, há necessidade de melhorar a gestão.

\section{As políticas públicas de repartição da competência entre os gestores}

Embora o art. 23, II, da Constituição Federal tenha instituído a competência comum, entendida como responsabilidade solidariedade, entre a União, os Estados, o Distrito Federal e os Municípios para cuidar da saúde, existem normas legais e infra legais fixando critérios de distribuição de atribuições e repartição de competência entre os gestores.

O presente trabalho não se destina a retratar a regulação administrativa de todas as normas de regulação e distribuição de atribuições e a repartição de competência entre os gestores, porque isso demandaria um trabalho específico. Pretende-se, analisar a eficácia das normas que distribuem obrigações entre os gestores.

A Lei $\mathrm{n}^{\circ}$ 8.080/90 dispõe no artigo 15 sobre as atribuições comuns da União, dos Estados, do Distrito Federal e dos Municípios, enquanto os artigos 16, 17 e 18 determinam a competência da direção nacional, da direção estadual e municipal do SUS, respectivamente.

$\mathrm{O}$ art. 15 da Lei $\mathrm{n}^{\circ}$ 8.080/90 atribui à União, aos Estados, ao Distrito Federal e aos Municípios a responsabilidade regulatória comum de organização, tais como: I - definição das instâncias e mecanismos de controle, avaliação e de fiscalização das ações e serviços de

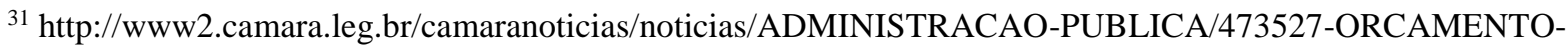
DE-2015 (acessado em 06.09.2014)

32 http://apsredes.org/site2012/wp-content/uploads/2012/08/GASTO-P\%C3\%9ABLICO-MUNICIPAL-EM-SA \%C3\% 9ADE-2011-GILSON-2.pdf. (acessado em 07.09.2014.
} 

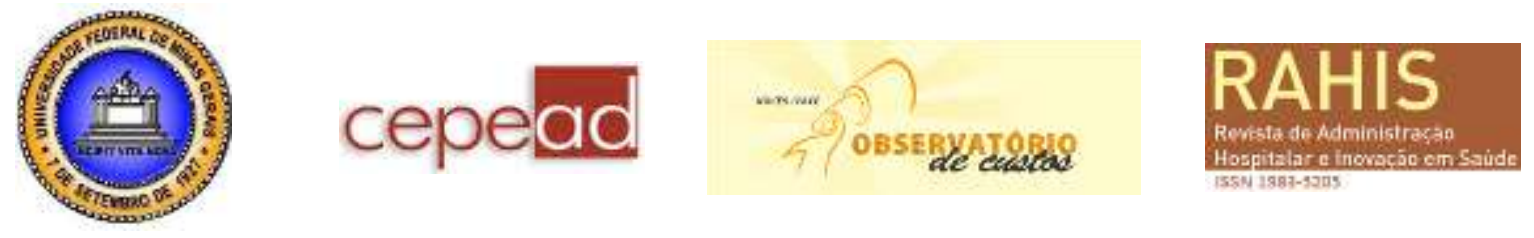

saúde; II - administração dos recursos orçamentários e financeiros destinados, em cada ano, à saúde; III - acompanhamento, avaliação e divulgação do nível de saúde da população e das condições ambientais; IV - organização e coordenação do sistema de informação de saúde; $V$ - elaboração de normas técnicas e estabelecimento de padrões de qualidade e parâmetros de custos que caracterizam a assistência à saúde; VI - elaboração de normas técnicas e estabelecimento de padrões de qualidade para promoção da saúde do trabalhador; VII participação de formulação da política e da execução das ações de saneamento básico e colaboração na proteção e recuperação do meio ambiente; VIII - elaboração e atualização periódica do plano de saúde; IX - participação na formulação e na execução da política de formação e desenvolvimento de recursos humanos para a saúde; $X$ - elaboração da proposta orçamentária do Sistema Único de Saúde (SUS), de conformidade com o plano de saúde; XI elaboração de normas para regular as atividades de serviços privados de saúde, tendo em vista a sua relevância pública; XII - realização de operações externas de natureza financeira de interesse da saúde, autorizadas pelo Senado Federal; XIII - para atendimento de necessidades coletivas, urgentes e transitórias, decorrentes de situações de perigo iminente, de calamidade pública ou de irrupção de epidemias, a autoridade competente da esfera administrativa correspondente poderá requisitar bens e serviços, tanto de pessoas naturais como de jurídicas, sendo-lhes assegurada justa indenização; XIV - implementar o Sistema Nacional de Sangue, Componentes e Derivados; XV - propor a celebração de convênios, acordos e protocolos internacionais relativos à saúde, saneamento e meio ambiente; XVI elaborar normas técnico-científicas de promoção, proteção e recuperação da saúde; XVII promover articulação com os órgãos de fiscalização do exercício profissional e outras entidades representativas da sociedade civil para a definição e controle dos padrões éticos para pesquisa, ações e serviços de saúde; XVIII - promover a articulação da política e dos planos de saúde; XIX - realizar pesquisas e estudos na área de saúde; XX - definir as instâncias e mecanismos de controle e fiscalização inerentes ao poder de polícia sanitária; XXI - fomentar, coordenar e executar programas e projetos estratégicos e de atendimento emergencial. Este artigo trata da responsabilidade comum (solidária) de natureza institucional ou sistêmica para implementação das políticas publicas. definidas:

Nos artigos 16 a 18 a LOS distribui as atribuições, repartindo competências, assim

a) A Direção Nacional teve a sua competência definida no art. 16, sendo: I-formular, avaliar e apoiar políticas de alimentação e nutrição; II - participar na formulação e na implementação das políticas: a) de controle das agressões ao meio ambiente; $b$ ) de saneamento básico; e c) relativas às condições e aos ambientes de trabalho; III - definir e coordenar os sistemas: a) de redes integradas de assistência de alta complexidade; $b$ ) de rede de laboratórios de saúde pública; c) de vigilância epidemiológica; e d) vigilância sanitária; $I V$ - participar da definição de normas e mecanismos de controle, com órgão afins, de agravo sobre o meio ambiente ou dele decorrentes, que tenham repercussão na saúde humana; $V$ participar da definição de normas, critérios e padrões para o controle das condições e dos ambientes de trabalho e coordenar a política de saúde do trabalhador; VI - coordenar e participar na execução das ações de vigilância epidemiológica; VII - estabelecer normas $e$ 

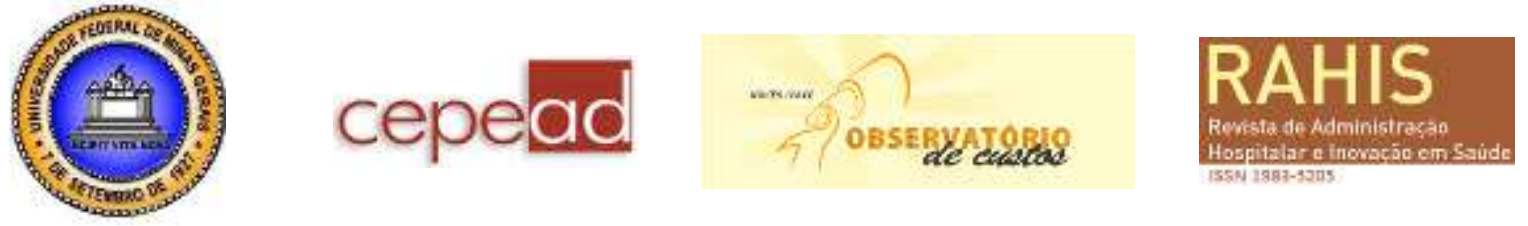

executar a vigilância sanitária de portos, aeroportos e fronteiras, podendo a execução ser complementada pelos Estados, Distrito Federal e Municípios; VIII - estabelecer critérios, parâmetros e métodos para o controle da qualidade sanitária de produtos, substâncias $e$ serviços de consumo e uso humano; IX - promover articulação com os órgãos educacionais e de fiscalização do exercício profissional, bem como com entidades representativas de formação de recursos humanos na área de saúde; $X$ - formular, avaliar, elaborar normas $e$ participar na execução da política nacional e produção de insumos e equipamentos para a saúde, em articulação com os demais órgãos governamentais; XI - identificar os serviços estaduais e municipais de referência nacional para o estabelecimento de padrões técnicos de assistência à saúde; XII - controlar e fiscalizar procedimentos, produtos e substâncias de interesse para a saúde; XIII - prestar cooperação técnica e financeira aos Estados, ao Distrito Federal e aos Municípios para o aperfeiçoamento da sua atuação institucional; XIV - elaborar normas para regular as relações entre o Sistema Único de Saúde (SUS) e os serviços privados contratados de assistência à saúde; $X V$ - promover a descentralização para as Unidades Federadas e para os Municípios, dos serviços e ações de saúde, respectivamente, de abrangência estadual e municipal; XVI - normatizar e coordenar nacionalmente o Sistema Nacional de Sangue, Componentes e Derivados; XVII acompanhar, controlar e avaliar as ações e os serviços de saúde, respeitadas as competências estaduais e municipais; XVIII - elaborar o Planejamento Estratégico Nacional no âmbito do SUS, em cooperação técnica com os Estados, Municípios e Distrito Federal; XIX - estabelecer o Sistema Nacional de Auditoria e coordenar a avaliação técnica e financeira do SUS em todo o Território Nacional em cooperação técnica com os Estados, Municípios e Distrito Federal. Ainda, de acordo com o parágrafo único do mesmo artigo, atribui à União a execução das ações de vigilância epidemiológica e sanitária em circunstâncias especiais, como na ocorrência de agravos inusitados à saúde, que possam escapar do controle da direção estadual do Sistema Único de Saúde (SUS) ou que representem risco de disseminação nacional.

b) À direção estadual o art. 17 da Lei $\mathrm{n}^{\circ}$ 8.080/90 atribui a seguinte competência: $I$ promover a descentralização para os Municípios dos serviços e das ações de saúde; II acompanhar, controlar e avaliar as redes hierarquizadas do Sistema Único de Saúde (SUS); III - prestar apoio técnico e financeiro aos Municípios e executar supletivamente ações e serviços de saúde; IV - coordenar e, em caráter complementar, executar ações e serviços: a) de vigilância epidemiológica; $b$ ) de vigilância sanitária; $c$ ) de alimentação e nutrição; $e$ d) de saúde do trabalhador; $V$ - participar, junto com os órgãos afins, do controle dos agravos do meio ambiente que tenham repercussão na saúde humana; VI - participar da formulação da política e da execução de ações de saneamento básico; VII - participar das ações de controle $e$ avaliação das condições e dos ambientes de trabalho; VIII - em caráter suplementar, formular, executar, acompanhar e avaliar a política de insumos e equipamentos para a saúde; IX - identificar estabelecimentos hospitalares de referência e gerir sistemas públicos de alta complexidade, de referência estadual e regional; $X$ - coordenar a rede estadual de laboratórios de saúde pública e hemocentros, e gerir as unidades que permaneçam em sua organização administrativa; XI - estabelecer normas, em caráter suplementar, para o 

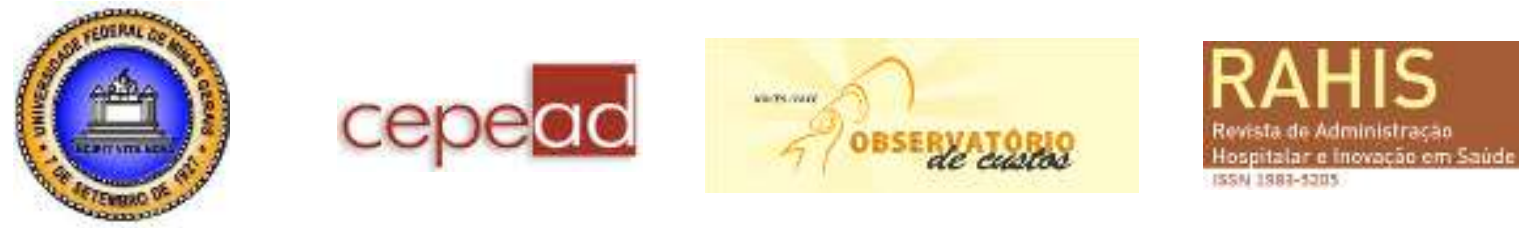

controle e avaliação das ações e serviços de saúde; XII - formular normas e estabelecer padrões, em caráter suplementar, de procedimentos de controle de qualidade para produtos $e$ substâncias de consumo humano; XIII - colaborar com a União na execução da vigilância sanitária de portos, aeroportos e fronteiras; XIV - o acompanhamento, a avaliação e divulgação dos indicadores de morbidade e mortalidade no âmbito da unidade federada. Verifica-se que a competência estadual fica mais por conta da coordenação, ficando com a responsabilidade executor suplementar das políticas, tornando-se responsável solidário pela organização das regiões de saúde, sendo responsável subsidiário, respondendo no caso de falha nos serviços prestados pelos Municípios.

c) À direção municipal o art. 18 da Lei no 8.080/90 renova o que já está determinado no art. 30, VII, da Constituição Federal, atribuindo-lhe a condição de executor direto com a seguinte competência: I - planejar, organizar, controlar e avaliar as ações e os serviços de saúde e gerir e executar os serviços públicos de saúde; II - participar do planejamento, programação e organização da rede regionalizada e hierarquizada do Sistema Único de Saúde (SUS), em articulação com sua direção estadual; III - participar da execução, controle e avaliação das ações referentes às condições e aos ambientes de trabalho; IV - executar serviços: a) de vigilância epidemiológica; b) vigilância sanitária; c) de alimentação $e$ nutrição; d) de saneamento básico; e e) de saúde do trabalhador; $V$ - dar execução, no âmbito municipal, à política de insumos e equipamentos para a saúde; VI - colaborar na fiscalização das agressões ao meio ambiente que tenham repercussão sobre a saúde humana e atuar, junto aos órgãos municipais, estaduais e federais competentes, para controlá-las; VII - formar consórcios administrativos intermunicipais; VIII - gerir laboratórios públicos de saúde e hemocentros; IX - colaborar com a União e os Estados na execução da vigilância sanitária de portos, aeroportos e fronteiras; $X$ - observado o disposto no artigo 26 desta Lei, celebrar contratos e convênios com entidades prestadoras de serviços privados de saúde, bem como controlar e avaliar sua execução; XI - controlar e fiscalizar os procedimentos dos serviços privados de saúde; XII - normatizar complementarmente as ações e serviços públicos de saúde no seu âmbito de atuação.

$\mathrm{O}$ art. 19 da Lei $\mathrm{n}^{\mathbf{0}}$ 8.080/90 deixa claro que ao Distrito Federal competem as atribuições tanto dos Estados como dos Municípios.

Aos Municípios foi atribuída a condição de principal executor das ações e serviços de saúde. Contudo, considerada a sua fragilidade financeira em relação ao Estado e a União, não há como exigir da direção municipal realizar atribuições que são dos outros dois gestores. A responsabilidade do Município se insere num federalismo solidário, mas não promíscuo, de modo que não há como desprezar as normas administrativas de repartição da competência.

$\mathrm{O}$ art. 14-A da Lei $\mathrm{n}^{\circ}$ 8.080/90, introduzido pela Lei $\mathrm{n}^{\circ} 12.466 / 2011$, legitimou a Comissão Intergestores Bipartite - CIB e Comissão Intergestores Tripartite - CIT, como foro de negociação para a repartição de competência quanto aos aspectos operacionais do SUS, de modo que lhe cabe fixar as regras e os limites de responsabilidade de cada ente.

O Decreto $\mathrm{n}^{\mathrm{o}}$ 7.508, de 28 de junho de 2011, é a norma administrativa que regulamenta a Lei $\mathrm{n}^{\circ} 8.080 / 90$, com o objetivo de organizar e planejar a política de saúde do SUS através da articulação interfederativa. Mais especificamente quanto à competência de 

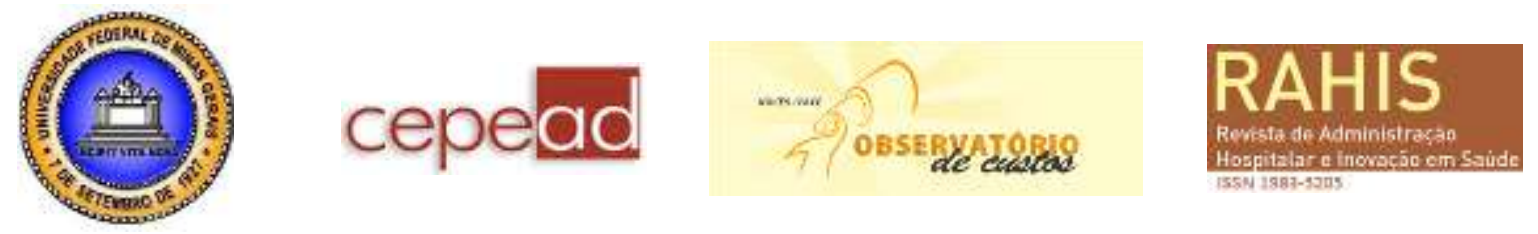

cada ente, estabelece o art. 35 que o "O Contrato Organizativo de Ação Pública da Saúde definirá as responsabilidades individuais e solidárias dos entes federativos com relação às ações e serviços de saúde". Além disso, no seu art. 32, atribui às Comissões Intergestores a competência para pactuar quanto à organização de repartição da competência.

O Ministério da Saúde é pródigo na edição de resoluções e portarias regulamentadoras do SUS, criando um verdadeiro cipoal normativo, elemento dificultador para a compreensão do sistema. Isso, contudo, não autoriza ao julgador desconsiderar que há um arcabouço normativo sobre a matéria, com a distribuição de atribuições e repartição de competências entre os gestores, com uma disciplina de hierarquização e articulação de ações em redes regionais do sistema de saúde.

Verifica-se que temos um norte legal a estabelecer regras de repartição de competências entre os gestores. Embora o julgador não tenha obrigação de conhecer todo o arcabouço de normas infra legais que regulam a saúde, não pode desprezar a sua vigência, decidindo comodamente pela regra de solidariedade constitucional absoluta, sem se preocupar com o consequencialismo jurídico, que poderá dificultar a sobrevivência financeira dos pequenos Municípios.

A título exemplificativo, vale lembrar algumas regras de distribuição de atribuições e repartição de competências.

O Componente Especializado de Atenção Farmacêutica está regulado pela Portaria $n^{\circ} 1554$, de 30 de julho de 2013, com regras claras de repartição da responsabilidades entre os gestores, ficando sua execução prioritariamente sob a responsabilidade do Estado-membro, com participação da União.

Quanto ao Componente Básico da Assistência Farmacêutica, a Portaria ${ }^{\circ} 1.555$, de 30 de julho de 2013, também traz normas de financiamento, contudo a execução fica prioritariamente sob a responsabilidade do Município.

No que se refere ao tratamento oncológico, está atualmente regulado pela Portaria $\mathrm{n}^{\circ}$ 140, de 27 de fevereiro de 2014, redefinindo os critérios e parâmetros para organização e planejamento, monitoramento, controle e avaliação dos estabelecimentos de saúde habilitados na atenção especializada em oncologia. Embora o serviço oncológico prestado pelos CACONS e UNACONS seja faturado pela União, o seu pagamento é extraído da dotação de cada Município no qual o paciente é domiciliado, que é o responsável pelo encaminhamento.

Por fim, no que se refere aos tratamentos de média e alta complexidade, o tratamento é realizada no micro ou macro região, de acordo com a organização das redes de atenção e as regiões de saúde. Ao Município que não tenha capacidade instalada e que não tenha assumida a responsabilidade na rede regionalizada, não é o responsável pelos tratamentos de média e de alta complexidade.

Os Municípios que possuem apenas atendimento na atenção básica, não são responsáveis pelos serviços de média e de alta complexidade, sobretudo quando esse atendimento tenha sido pactuado com o Município sede de região de saúde. Por seu turno, o Estado-Membro tem a obrigação de organizar e instituir a rede regionalizada e hierarquizada, considerando complexidade do atendimento e a capacidade instalada de cada município, que poderá ou não optar pela gestão municipal (gestão plena). 

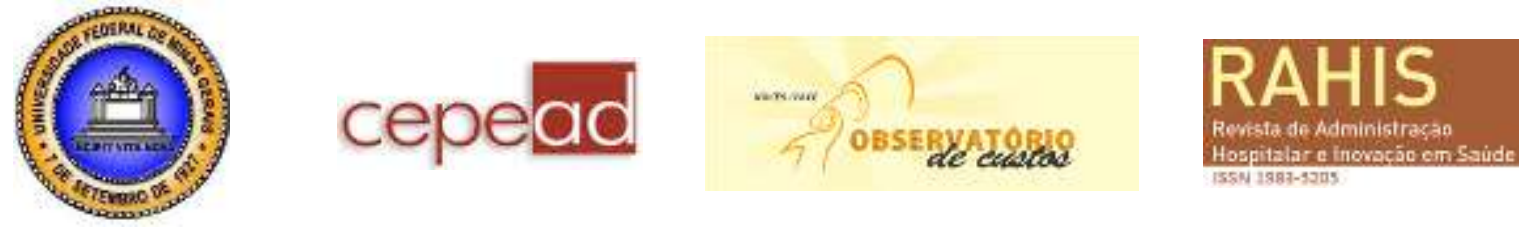

Aos Municípios que não possuem capacidade instalada e que não tenham assumido determinados tratamentos cabe encaminhar seus pacientes para a rede regional de saúde de atendimento da média e alta complexidade. A execução dos serviços de média e alta complexidade será do Município que possui capacidade instalada e que tenha assumido essa atribuição. Os Municípios com gestão municipal que assumem, os serviços mais complexos são remunerados por isso, inclusive recebendo verbas diretamente da União. Portanto, o Município-sede da rede regional é responsável pelos serviços das unidades da região, sem que isso exclua a responsabilidade do Estado, que responde subsidiariamente pelos defeitos no serviço que lhe cabe organizar.

Uma vez instituído um arcabouço jurídico de distribuição das atribuições, conforme delegação dos artigos 197 e 198 da Constituição Federal, orientando a diretriz organizacional dos serviços de saúde num sistema com descentralização político-administrativa, com regionalização e hierarquização da rede de serviços de saúde, ocorreu o fracionamento da solidariedade sistêmica ou institucional instituída no art. 23, II da Constituição Federal, que se converte em responsabilidade subsidiária. No sistema de saúde brasileiro, o art. 198 da Constituição Federal foi regulamentado pela Lei $n^{\circ} 8.080 / 90$, esta que também foi regulada pelo Decreto 7.508/2011. Além disso, não pode ser desprezado que há inúmeras outras normas infra legais que regulam a saúde pública.

Importa acentuar que não há como exigir que os três gestores, que são entes políticos independentes, criem estruturas similares para a realização de atividades idênticas e prestem os mesmos serviços, o que representaria violação ao princípio da eficiência, que também rege a administração pública (CF, art. 37). Aliás, a Lei Orgânica da Saúde (Lei no 8.080/90) incluiu dentre os princípios orientadores do SUS a organização dos serviços públicos para evitar duplicidade de meios para fins idênticos (art. $7^{\circ}$, XIII).

Cabe recorrer a salutar ponderação de Lenir do Santos de que,

As responsabilidades dos entes federativos pelo financiamento $e$ pelo "fazer" devem estar disciplinadas em atos jurídicos que consubstanciem os direitos e deveres desses entes na gestão compartilhada da saúde. ${ }^{33}$

Aliás, ao decidir a STA-CE $\mathrm{n}^{\mathrm{o}} 175$, o relator, Ministro Gilmar Mendes, deixou expresso que "em geral, deverá ser privilegiado o tratamento fornecido pelo SUS em detrimento de opção diversa escolhida pelo paciente, sempre que não for comprovada a ineficácia ou impropriedade da política de saúde existente", embora admita em seu voto que isso também não afasta "a possibilidade de o Poder Judiciário, ou de a própria Administração, decidir que medida diferente da custeada pelo SUS deve ser fornecida a

\footnotetext{
${ }^{33}$ SANTOS, Lenir (Org) Direito à saúde e Sistema Único de Saúde: conceito e atribuições. O que são ações e serviços de saúde. In: Direito da Saúde no Brasil. Campinas: Saberes, 2010, p. 164.
} 

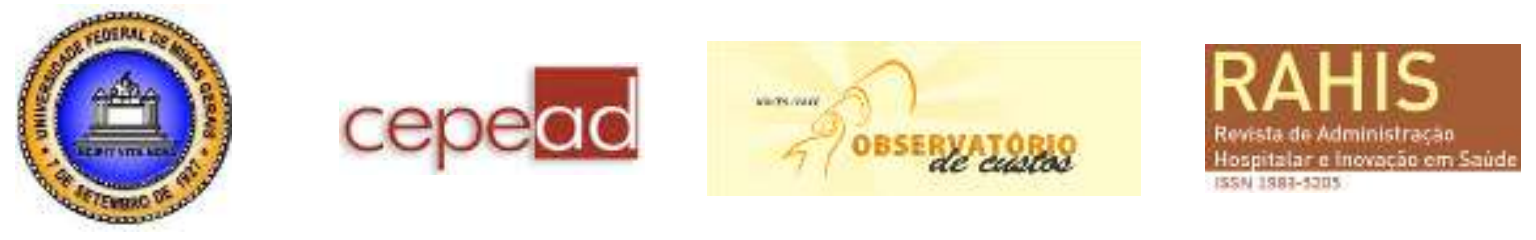

determinada pessoa que, por razões específicas do seu organismo, comprove que o tratamento fornecido não é eficaz no seu caso".

O Supremo Tribunal Federal também reconhece a necessidade de ser "construído um modelo de cooperação e de coordenação de ações conjuntas por parte dos entes federativos". Ora, qualquer modelo de cooperação e coordenação de ações conjuntas somente se estabelece se houver clara distribuição de atribuições entre os gestores, como recomenda o art. 198 da Constituição Federal.

O fracionamento da solidariedade com a sua transformação em subsidiariedade é reconhecida pelo Ministro Gilmar Mendes no seu voto ao decidir a STA 175-CE, ao argumentar:

O fato de o Sistema Único de Saúde ter descentralizado os serviços e conjugado os recursos financeiros dos entes da Federação, com o objetivo de aumentar a qualidade e o acesso aos serviços de saúde, apenas reforça a obrigação solidária e subsidiária entre eles."

"As ações e os serviços de saúde são de relevância pública, integrantes de uma rede regionalizada e hierarquizada, segundo o critério da subsidiariedade, e constituem um sistema único.” (Min. Gilmar Mendes STA n ${ }^{\circ}$ 175-CE 17.03.2010)

Desse modo, ao reconhecer que nas demandas judiciais devem ser prestigiadas as políticas públicas instituídas, deve-se entender também que isso se aplica para as regras de repartição da competência entre os gestores, transformando a obrigação em princípio solidária em subsidiária.

Ao julgador cabe analisar as normas constitucionais, as infraconstitucionais e as infra legais que regulam as políticas públicas para decidir quanto a aplicabilidade das regras de descentralização e repartição de competência entre os gestores.

$\mathrm{O}$ art. 23, II, da Constituição Federal apenas instituiu uma solidariedade institucional ou sistêmica, impondo aos três entes (União, Estados e Municípios) a obrigação de regularem e instituírem as políticas públicas de saúde. Essa, aliás, é a orientação do art. 198 da Constituição Federal, a partir da qual foi editada a Lei Complementar $n^{\circ} 141 / 2012$, as Leis $n^{\circ}$ 8.080/90 e $\mathrm{n}^{\circ}$ 8.142/90, o Decreto $n^{\circ} 7.508 / 2012$, além de inúmeras Resoluções e Portarias, estabelecendo regras sobre os procedimentos e responsabilidades, repartindo assim as atribuições entre os gestores.

Portanto, somente na ausência de políticas públicas aplica-se a regra da solidariedade institucional ou sistêmica do art. 23, II, da Constituição Federal, contudo, a partir do momento em que as normas legais e infralegais distribuíram atribuições, passou a existir uma repartição de competência entre os gestores, fracionando-se a solidariedade que se transforma em subsidiariedade.

\section{O impacto deslocativo no orçamento e a cláusula da reserva do possível}



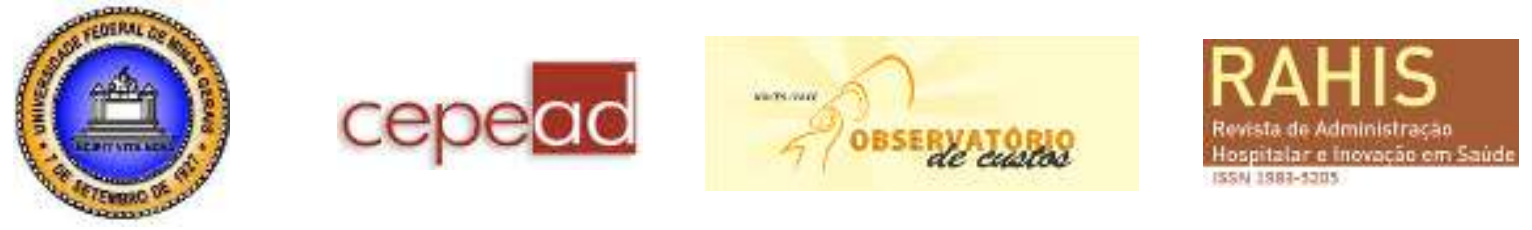

Como visto, a Constituição Federal delegou à legislação complementar e ordinária a edição de normas para organização do sistema de saúde, razão pela qual dotação orçamentária da saúde da União, dos Estados, do Distrito Federal e dos Municípios é organizada com base nas atribuições que cada um possui quanto às ações e serviços de saúde.

Ocorre que boa parte do Poder Judiciário se limita a uma interpretação isolada do art. 23, II, da Constituição Federal, sob a visão de que a solidariedade é absoluta, não atentando ao fato de que existe um arcabouço jurídico que regula a saúde por meio de normas legais e infralegais que distribuem atribuições, repartindo a competência entre os gestores.

O próprio Supremo Tribunal Federal ainda mantém uma orientação, data vênia, equivocada no sentido de que a solidariedade do art. 23, II, da Constituição Federal resistindo à possibilidade de fracionamento da responsabilidade comum pela transformação daquela responsabilidade em subsidiária. De outro lado aquela Corte tem reconhecido a necessidade de privilegiar as políticas públicas em detrimento de medicamentos ou procedimentos diferentes, sem comprovação da ineficácia daqueles oferecidos pelo SUS e de que existe um modelo de obrigação solidária e subsidiária.

As falhas nos serviços de saúde, como decorrência do subfinanciamento e da falta de coordenação da gestão, têm levado a uma escala exponencial da judicialização do acesso à saúde, contudo, as decisões judiciais não atenuam as falhas do serviço, servindo apenas para solucionar casos isolados, muitas vezes em prejuízo da coletividade, agrava ainda mais os problemas da gestão, sobretudo quando desconsideram as regras de distribuição de atribuições e repartição de competências.

Embora não se possa negar o acesso ao Poder Judiciário para assegurar o acesso aos serviços de saúde, não há dúvida que por vezes essas decisões podem causar uma verdadeira desordem nas rubricas orçamentárias, criando o chamado impacto deslocativo no orçamento, porque impõem de despesas muitas vezes não previstas nas rubricas orçamentárias em execução.

A propósito, sobre o impacto deslocativo no orçamento acentua Sebastião Castro:

Um provimento jurisdicional que ordene o atendimento público de determinada necessidade médica fora do estabelecido pelas normas e regulamentos do Sistema Único de Saúde (SUS) ou à revelia das políticas públicas traçadas dentro das limitações orçamentárias do Poder Público - age em desfavor de toda a coletividade, pois atende a uma necessidade individual em detrimento do equilíbrio financeiro do sistema e subverte, portanto, os próprios direitos fundamentais, que, a princípio, pretendeu garantir. ${ }^{34}$

\footnotetext{
${ }^{34}$ CASTRO, Sebastião Helvécio Ramos. Impacto deslocativo no orçamento público estadual em face de decisões judiciais. In.: Controle Externo - Estudos Temáticos. GUERRA, Evandro Martins; CASTRO Sebastião Helvécio Ramos de (Coord). Belo Horizonte: Forum, 2012. P.44.)
} 

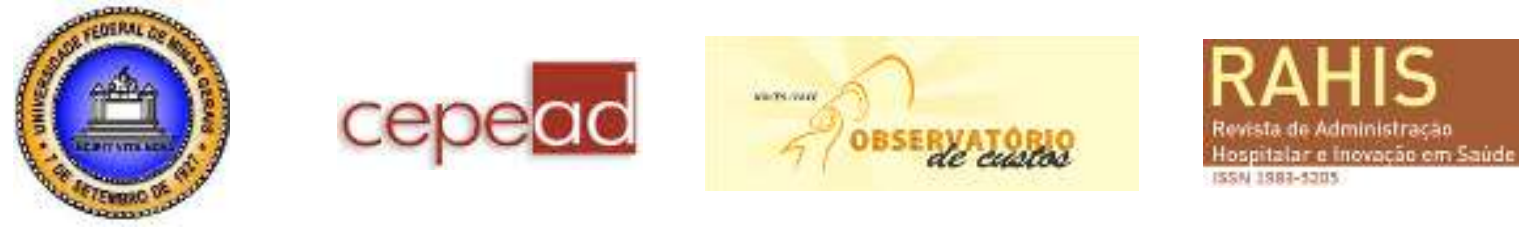

O art. 37 da Constituição Federal contempla o princípio da eficiência da administração pública, e a imposição de serviços para um ente quando a regulação o destina a outro causa uma verdadeira desordenação do serviço, que terá impactos absolutamente negativos na gestão pública.

Embora no art. 35, VII, da Lei 8.080/90 esteja previsto o ressarcimento do atendimento a serviços prestados para outras esferas de governo, não se pode desprezar que inexiste um fluxo automático de ressarcimento administrativo, de modo que impor ações e serviços de outro ente pode impactar negativamente o orçamento, sobretudo se isso for imposto a pequenos Municípios.

O Poder Judiciário não pode desconsiderar as normas de regulação administrativa da saúde, devendo o julgador ficar atento ao impacto da desestruturação orçamentária que suas decisões podem provocar, até porque existe uma estrutura administrativa hierarquizada no SUS. A Constituição Federal apenas fixou as diretrizes para a organização do sistema, cuja regulação administrativa cabe às normas infraconstitucionais.

As decisões judiciais devem ser tomadas levando em conta a repercussão que terão na esfera administrativo-orçamentária, de modo que o magistrado deve ficar atento ao que se chama de consequencialismo jurídico da sua decisão, porque podem irradiam impactos sociais e econômicos que as vezes transcendem a própria lide, eventualmente tornando inviável a gestão administrativa, sobretudo de pequenos Municípios.

\section{Os desafios do Sistema Único de Saúde}

As políticas de saúde pública têm o desafio de instituir os meios necessários que efetivem o acesso universal e igualitário, com o atendimento integral, para assegurar condições dignas dentro da medicina baseada em evidência.

Além de melhorar financiamento é especialmente crucial que o SUS atenda orientação do art. 198 da Constituição Federal e institua a rede de atenção à saúde, porque não haverá melhoria no atendimento ao cidadão caso não seja melhorada a gestão de saúde.

A ineficiência do Sistema Único de Saúde e o desperdício de recursos destinados à saúde despertou a atenção do Tribunal de Contas da União - TCU, que proferiu o acórdão $\mathrm{n}^{\circ}$ 6932014, na sessão de 26.03.2014, no processo TC 032.624/2013-1, relatado pelo Ministro Benjamn Zymler, um relatório sistêmico sobre a situação da saúde no Brasil, que traçou um diagnóstico da saúde pública no Brasil, com a finalidade de subsidiar a estruturação das redes de saúde. ${ }^{35}$

Em razão de constatação da deficiência na gestão de saúde, decorrente de problemas de governança pública e da falta de implementação e organização da rede de atenção e regiões de saúde, como causa de ineficiência e com prejuízo ao erário dos gastos com saúde, o Instituto Rui Barbosa - IRB também realizou nos dias 28 a 31 de julho de 2014, encontro no

\footnotetext{
${ }^{35}$ https://contas.tcu.gov.br/juris/Web/Juris/ConsultarTextual2/Jurisprudencia.faces?grupoPesquisa=JURISPRUD ENCIA\& textoPesquisa=PROC:3262420131 (acessado em 02.8.2014)
} 

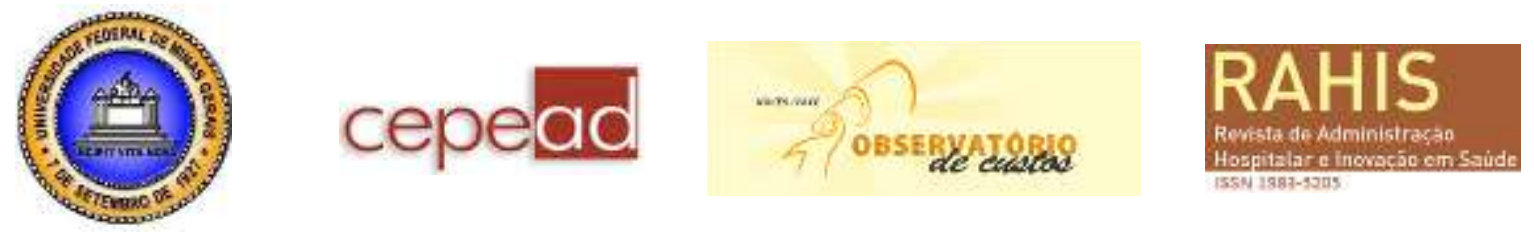

TCU, que reuniu representantes de vinte e nove Tribunais de Contas para discutir a realização de auditorias coordenadas, que discutiram em oficinas "o alinhamento dos três grandes eixos da Auditoria Coordenada: 1) Gestão de Pessoas, com dois subitens: capacitação/formação e locação/permanência; 2)Avaliação e Monitoramento com discussão crítica dos indicadores e suporte da TI; 3) Planejamento com as questões alusivas ao levantamento das necessidades de saúde e identificação das regiões de saúde e redes de atenção," ${ }^{36}$ da qual resultou a elaboração de uma matriz para a Auditoria Coordenada em Atenção Básica no Brasil, visando subsidiar a estruturação de redes de atenção à saúde.

O subfinanciamento do Sistema Único de Saúde é apenas uma dos problemas, porque o principal desafio é o de otimizar e qualificar a gestão de saúde, com a efetiva organização e implantação das redes de atenção e regiões de saúde, de modo que o atendimento seja integral a partir da atenção básica e o encaminhamento dos problemas mais graves para a média e a alta complexidade.

Enfim, o principal desafio do SUS é a criação das redes regionais de atenção à saúde, com o fortalecimento da atenção básica, de modo a evitar o agravamento de enfermidades com a evolução para a média e a alta complexidade.

\section{Conclusão.}

A Constituição Federal assegura o acesso à saúde pública de forma universal e igualitária, com atendimento integral. Isso significa dizer que não pode haver limitação de acesso a qualquer pessoa (rica ou pobre), a qualquer medicamento ou tratamento, em relação ao qual haja prova da evidência científica, ou seja, eficácia, eficiência, efetividade e segurança, além da prova de sua necessidade ao paciente e de que não esteja incluído nos protocolos clínicos das políticas públicas.

Embora a integralidade constitucionalmente assegurada garanta o acesso a qualquer tratamento ou medicamento, isso não significa dizer que deve ser concedido tudo para todos, o se deve é privilegiar os produtos oferecidos pelo sistema público de saúde em detrimento do pretendido pelo usuário, se possuir a mesma eficácia terapêutica.

O Poder Público tem o desafio de organizar o SUS com a efetiva implantação e operacionalização da rede de atenção à saúde, garantindo que se assegure o acesso universal e igualitário. $\mathrm{O}$ tratamento deve iniciar pelo diagnóstico na atenção básica, prosseguimento com tratamento na rede regionalizada e hierarquizada para garantir o atendimento da média e da alta complexidade, concretizando, assim, o atendimento integral conforme diretriz do art. 198 da Constituição Federal.

A falta de acesso universal e igualitário na atenção básica levará, fatalmente, ao agravamento de enfermidades com evolução para a média e alta complexidade, elevando os custos. Além disso, a falta de um fluxo hierarquizado de atendimento, em tempo razoável, leva os usuários a reclamar ao Poder Judiciário o acesso a produtos de saúde o acesso à saúde.

\footnotetext{
$36 \mathrm{http} / / / \mathrm{www}$.irbcontas.org.br/noticia/encontro-reune-representantes-do-irb-tcu-e-tc-s/441 - (acessado em 02.08.2014)
} 

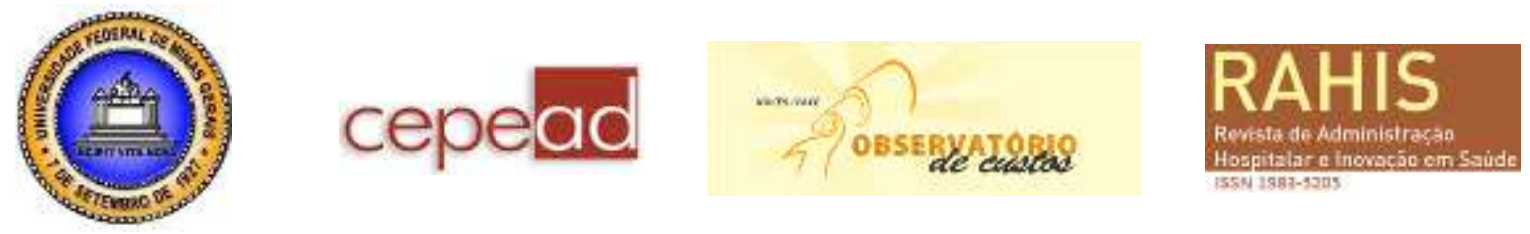

A judicialização do acesso à saúde e o protagonismo judicial, são, pois, consequências do descumprimento da garantia de acesso universal e igualitária com atendimento integral.

A complexa organização do SUS somado ao desconhecimento da técnica médica cria dificuldades para os operadores jurídicos compreenderem a sua regulação. Isso acaba levando o Poder Judiciário a proferir decisões às vezes equivocadas, com isso subvertendo a ordem administrativa da gestão, desprezando regras de repartição de competência e distribuição de atribuições, além de assegurar o acesso a procedimentos e medicamentos sem evidência científica de melhor resultado do que aqueles oferecidos pelo SUS, impactando negativamente o orçamento público e sem melhorias para o paciente, em prejuízo da coletividade.

Em função das considerações expostas, conclui-se:

a) Cabe ao Poder Pública organizar o Sistema Único de Saúde de modo a dar efetividade ao acesso universal e igualitário, com especial valorização da atenção básica, a fim de detectar precocemente as enfermidades, evitando o seu agravamento.

b) Também cabe ao Poder Público a efetiva implantação da rede regionalizada e hierarquizada de modo que se atinja o atendimento integral da média e alta complexidade.

c) Ao decidir, o Poder Judiciário deve ficar atendo ao norte legal que instituiu regras administrativas de organização das políticas públicas de saúde, inclusive quanto à repartição das competências, evitando desse modo de se impor a criação da duplicidade de meios para fins idênticos, porque violará ao princípio da eficiência da administração pública.

d) Igualmente o Poder Judiciário deve ficar atento a que, embora esteja assegurado o acesso universal e igualitário com atendimento integral à saúde, há necessidade de decidir apenas com base em prova de evidência científica, de modo que somente seja autorizado o acesso a produtos não incorporados nas políticas públicas quando comprovado que aqueles oferecidos são ineficazes ou ineficientes em razão da condição peculiar do paciente que os reclama.

e) Por fim, cabe ao Estado brasileiro, sobretudo ao Poder Judiciário encontrar meios de prestigiar a macro justiça, realizada através das ações coletivas que visam a melhoria do serviço de saúde e a incorporação de novas tecnologias. A micro justiça, realizada pelas ações individuais, deve ficar 

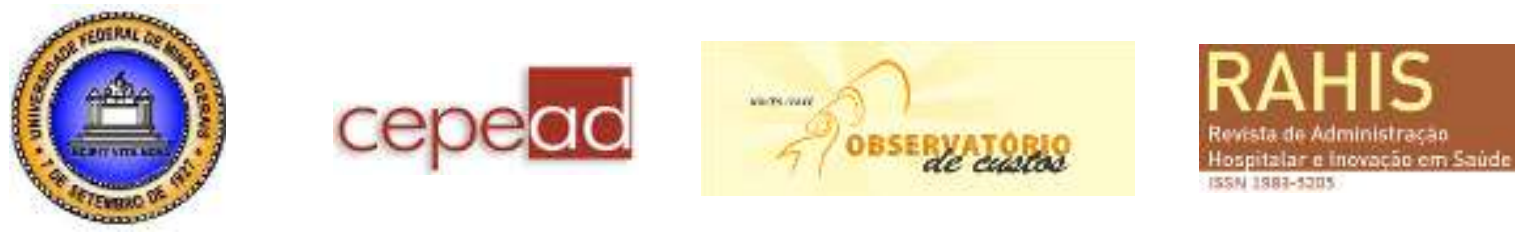

reservadas para aquelas hipóteses em que as políticas públicas já instituídas estiverem sendo descumpridas, evitando-se a reiterada intervenção na gestão administrativa, inclusive com o deslocamento de rubricas orçamentárias.

\section{Referência bibliográfica}

ASSIS, Gilmar de. SUS para todos: Breves reflexões jurídico-sociais. Avanços e desafios. In: Saúde: ALMEIDA, Gregório Assagra de; SOARES Jr., Jarbas; ASSIS, Gilmar de (coord). Belo Horizonte: Del Rey, 2013.

BARCELLOS, Ana Paula de. A eficácia jurídica dos princípios constitucionais. $3^{\mathrm{a}} \mathrm{ed}$. Rio de Janeiro: Renovar, 2011.

BARROSO, Luís Roberto. Da falta de efetividade à judicialização excessiva: direito à saúde, fornecimento gratuito de medicamentos e parâmetros para a atuação judicial. Revista de Jurisprudência Mineira, a. 60, n. 188, Belo Horizonte, p. 35-50, jan./mar. 2009

BARROSO, Luís Roberto. O novo direito constitucional brasileiro. Belo Horizonte: Fórum, 2014.

BRASIL - RE-AGR Nº 393175/RS, $2^{\text {a }}$ TURMA, REL. MIN. CELSO DE MELLO, DJ 02-022007

BRASIL. Supremo Tribunal Federal. STA-AgR 175/CE. Agravo Regimental em Suspensão de Tutela Antecipada. Relator: Ministro Gilmar Mendes (presidente). Julgamento: 17 mar. 2010. Publicação DJ 30 abr. 2010.

BRASIL. http://www2.camara.leg.br/camaranoticias/noticias/ADMINISTRACAO-PUBLICA /473527-ORCAMENTO-DE-2015)

CANOTILHO,J.J. Gomes; CORREIA, Marcus Orione Gonçalves; CORREIA, Érica Paula Barcha. (coord.) O direito dos pobres no activismo judiciário. In: Direitos Fundamentais Sociais. São Paulo: Saraiva, 2010.

CASTRO, Sebastião Helvécio Ramos. Impacto deslocativo no orçamento público estadual em face de decisões judiciais. In.: Controle Externo - Estudos Temáticos. GUERRA, Evandro Martins; CASTRO Sebastião Helvécio Ramos de (Coord). Belo Horizonte: Forum, 2012.

FIRMO, Osvaldo Oliveira Araújo. Direito à Saúde: Reflexão sobre a ética da decisão judicial. In: Revista do Instituto dos Magistrados do Ceará. Ano 14, nº $29 / 30$ (jan./dez.). Fortaleza: 2011. 

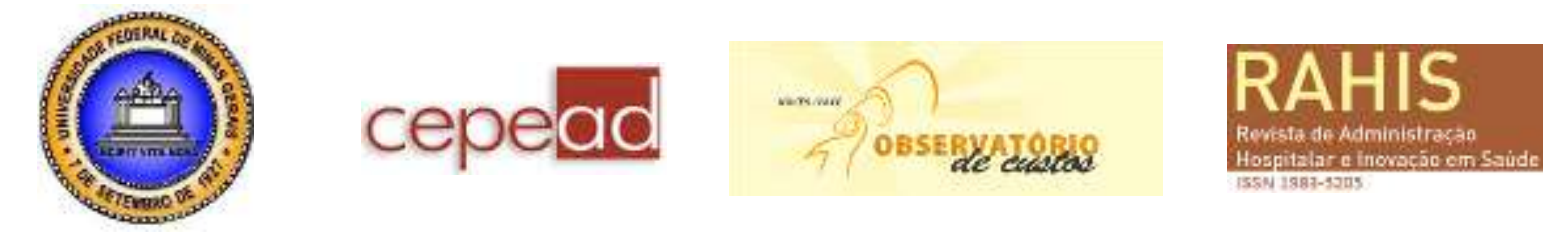

http://apsredes.org/site2012/wp-content/uploads/2012/08/GASTO-P\%C3\%9ABLICOMUNICIPAL-EM-SA\%C3\%9ADE-2011-GILSON-2.

http://www.cnj.jus.br/images/programas/forumdasaude/demandasnostribunais.forumSaude http://www.ipea.gov.br/portal/index.php

http://www.paho.org/bra/index.php?option=com_content\&view=article\&id=3142 Itemid

LEDUR, José Felipe. Os direitos fundamentais sociais. Porto Alegre: Livraria do Advogado, 2009.

ROSS, Elisabeth Kübler. Sobre a morte e o morrer. São Paulo: Martins Fontes, 2012, p. 06.

SANTOS, Lenir (Org) Direito à saúde e Sistema Único de Saúde: conceito e atribuições. O que são ações e serviços de saúde. In: Direito da Saúde no Brasil. Campinas: Saberes, 2010.

SARLET, Ingo Wolfgang. A eficácia dos direitos fundamentais. $11^{\mathrm{a}}$ ed. Porto Alegre: Livraria do Advogado, 2012.

SILVA, José Afonso da. Comentário Contextual à Constituição. $3^{\text {a }}$ ed. São Paulo: Malheiros, 2007.

STRECK, Lenio Luiz. Jurisdição constitucional e decisão jurídica. $4^{\mathrm{a}}$ ed. São Paulo: RT, 2013.

TORRES, Ricardo Lobo. O direito ao mínimo existencial. Rio de Janeiro: Renovar, 2009. 